\title{
Identifying Functional Impacts of Heat-Resistant Fungi on Boreal Forest Recovery After Wildfire
}

\section{OPEN ACCESS}

Edited by:

Tina Bell,

University of Sydney, Australia

Reviewed by:

Adriana Lucia Romero-Olivares,

University of New Hampshire,

United States

Tatiana Semenova-Nelsen, University of Kansas, United States

*Correspondence:

Nicola J. Day

njday.ac@gmail.com

tPresent address:

Nicola J. Day,

School of Science, Auckland University of Technology, Auckland,

New Zealand

Kirsten A. Reid,

Department of Geography, Memorial

University of Newfoundland, St.

John's, NL, Canada

Specialty section:

This article was submitted to

Fire and Forests,

a section of the journal

Frontiers in Forests and Global

Change

Received: 25 October 2019

Accepted: 11 May 2020

Published: 09 June 2020

Citation:

Day NJ, Cumming SG, Dunfield KE, Johnstone JF, Mack MC, Reid KA, Turetsky MR, Walker XJ and Baltzer JL (2020) Identifying Functional Impacts

of Heat-Resistant Fungi on Boreal Forest Recovery After Wildfire. Front. For. Glob. Change 3:68. doi: 10.3389/ffgc.2020.00068
Nicola J. Day ${ }^{1 * \dagger}$, Steven G. Cumming ${ }^{2}$, Kari E. Dunfield ${ }^{3}$, Jill F. Johnstone ${ }^{4,5}$, Michelle C. Mack ${ }^{6}$, Kirsten A. Reid ${ }^{17}$, Merritt R. Turetsky ${ }^{7}$, Xanthe J. Walker ${ }^{6}$ and Jennifer L. Baltzer ${ }^{1}$

${ }^{1}$ Biology Department, Wilfrid Laurier University, Waterloo, ON, Canada, ${ }^{2}$ Department of Wood and Forest Sciences, Laval University, Quebec City, QC, Canada, ${ }^{3}$ School of Environmental Sciences, University of Guelph, Guelph, ON, Canada, ${ }^{4}$ Department of Biology, University of Saskatchewan, Saskatoon, SK, Canada, ${ }^{5}$ Institute of Arctic Biology, University of Alaska Fairbanks, Fairbanks, AK, United States, ${ }^{6}$ Center for Ecosystem Science and Society, Northern Arizona University, Flagstaff, AZ, United States, ${ }^{7}$ Institute of Arctic and Alpine Research, University of Colorado Boulder, Boulder, CO, United States

Fungi play key roles in carbon (C) dynamics of ecosystems: saprotrophs decompose organic material and return $\mathrm{C}$ in the nutrient cycle, and mycorrhizal species support plants that accumulate $\mathrm{C}$ through photosynthesis. The identities and functions of extremophile fungi present after fire can influence $\mathrm{C}$ dynamics, particularly because plant-fungal relationships are often species-specific. However, little is known about the function and distribution of fungi that survive fires. We aim to assess the distribution of heat-resistant soil fungi across burned stands of boreal forest in the Northwest Territories, Canada, and understand their functions in relation to decomposition and tree seedling growth. We cultured and identified fungi from heat-treated soils and linked sequences from known taxa with high throughput sequencing fungal data (Illumina MiSeq, ITS1) from soils collected in 47 plots. We assessed functions under controlled conditions by inoculating litter and seedlings with heat-resistant fungi to assess decomposition and effects on seedling growth, respectively, for black spruce (Picea mariana), birch (Betula papyrifera), and jack pine (Pinus banksiana). We also measured litter decomposition rates and seedling densities in the field without inoculation. We isolated seven taxa of heat-resistant fungi and found their relative abundances were not associated with environmental or fire characteristics. Under controlled conditions, Fayodia gracilipes and Penicillium arenicola decomposed birch, but no taxa decomposed black spruce litter significantly more than the control treatment. Seedlings showed reduced biomass and/or mortality when inoculated with at least one of the fungal taxa. Penicillium turbatum reduced growth and/or caused mortality of all three species of seedlings. In the field, birch litter decomposed faster in stands with greater pre-fire proportion of black spruce, while black spruce litter decomposed faster in stands experiencing longer fire-free intervals. Densities of seedlings that had germinated since fire were positively associated with ectomycorrhizal richness while there were fewer conifer seedlings with greater 
heat-resistant fungal abundance. Overall, our study suggests that extremophile fungi present after fires have multiple functions and may have unexpected negative effects on forest functioning and regeneration. In particular, heat-resistant fungi after fires may promote shifts away from conifer dominance that are observed in these boreal forests.

Keywords: mycorrhiza, saprotroph, Taiga plains, boreal, Northwest Territories, seedlings, litter decomposition, extremophile

\section{INTRODUCTION}

Soil fungi form an important link between aboveground and belowground pools of carbon (C) in forests (Baldrian, 2017). These heterotrophs can acquire $\mathrm{C}$ by decomposing organic material (saprotrophs), which influences belowground C, and by forming symbiotic relationships with plant roots and enhancing plant growth (mycorrhizas), thereby affecting aboveground C (Smith and Read, 2008). Non-mycorrhizal fungi, such as pathogens and endophytes, can also colonize roots and either decrease or increase plant growth (Jarosz and Davelos, 1995; Agrios, 2005; Porras-Alfaro and Bayman, 2011). Plant-fungal interactions are sometimes species-specific (Bent et al., 2011; Treseder et al., 2014; Sterkenburg et al., 2015); saprotrophic fungal taxa can have affinities for litter from different plant species (Treseder et al., 2014) and a fungal taxon that promotes growth of one plant species may reduce growth of another species (Klironomos, 2002). A single fungal taxon or isolate can also have multiple functions (Shah et al., 2016; Smith et al., 2017), making it challenging to draw conclusions about function from DNA sequences alone. Experimental studies can enhance knowledge of fungal functions and elucidate how direct and indirect effects of fires on fungal communities may impact aboveground and belowground C.

Boreal forests are an important $\mathrm{C}$ sink; an estimated one-third of global terrestrial $\mathrm{C}$ is stored in these forests and most of this is in the soils (Pan et al., 2011). The majority of C combusted in boreal forest fires is from the soil (Boby et al., 2010; Rogers et al., 2014; Walker et al., 2018a). Thus, accumulation of belowground $\mathrm{C}$ between consecutive fires is critical to maintaining these soils as net C sinks (Andrieux et al., 2018; Walker et al., 2019). Accumulation of deep organic soil layers in boreal forests is often attributed to slow decomposition rates due to dominance of plants with recalcitrant material, mainly conifers, combined with cold temperatures that limit microbial activity, such as bacteria and fungi (Prescott et al., 2000; Fenton et al., 2005). However, fungi are key drivers of accumulation of soil organic matter in boreal forests (Kyaschenko et al., 2017). In terms of accumulation of aboveground C, fungi and other microbes influence plant growth and community structure (Hewitt et al., 2013; Duhamel et al., 2019). Although microbes play central roles in C cycling in boreal forests (Kyaschenko et al., 2017), our knowledge of the impact of boreal wildfires in these ecosystems on soil microbial functioning is limited.

Fire activity is projected to increase in many regions of the world with climate change, as is already observed in boreal forests of western North America (Kasischke and Turetsky,
2006; Wotton et al., 2017; Coops et al., 2018). Increased fire intensity, fire severity, and frequency may be causing state changes in dominant vegetation and function in boreal forests (Fenton, 2016; Johnstone et al., 2016). In boreal forest stands, fire often causes $100 \%$ tree mortality and there is a flush of recruitment of tree seedlings in the initial years following fire that sets the successional trajectory for future decades (Johnstone et al., 2004; Shenoy et al., 2011). There are increasing observations of shifts away from black spruce (Picea mariana) dominance toward jack pine (Pinus banksiana) or deciduous species such as paper birch (hereafter birch; Betula papyrifera/B. alaskana) or trembling aspen (Populus tremuloides; Johnstone et al., 2010; Boiffin and Munson, 2013; Whitman et al., 2018). Post-fire soil microbial communities could affect this change through differential positive or negative impacts on regenerating plant communities with implications for plant successional trajectories and accumulation of aboveground C. Likewise, postfire microbial communities may differentially influence litter decomposition depending on plant species, with implications for organic soil layers and sequestration of belowground C (Laganière et al., 2010; Treseder et al., 2014). Fire characteristics including fire intensity, fire severity, and fire return interval can influence post-fire microbial community structure (Glassman et al., 2016; Day et al., 2019), necessitating an enhanced understanding of the impacts of fire on soil microbial community structure and the associated coupled plant-soil responses.

Fire is a strong filter on biotic communities, even in fireadapted systems, and may promote survival or germination of extremophiles such as heat-resistant fungi (Suryanarayanan et al., 2011). For example, nearly 40 macrofungal species that need fire to produce spores, most of which are saprotrophs, have been identified in Fennoscandian boreal forests (Dahlberg, 2002). Saprotrophs are generally less susceptible to fires than mycorrhizas and need less time to recover after fire (Treseder et al., 2004; Sun et al., 2015; Holden et al., 2016). However, heat-resistant spores of the ectomycorrhizal fungus Rhizopogon olivaceotinctus enables it to increase in abundance after fire in montane forests in California (Izzo et al., 2006; Peay et al., 2009; Glassman et al., 2016). Fires that burn deeper into the soil organic layer may expose fire-adapted spores from a previous fire cycle that have declined in frequency or abundance through succession. Fungi may also be insulated from heat in organic soil layers and survive via mycelial networks or within roots (Hewitt et al., 2017; Birnbaum et al., 2019). In the upper soil layers, species-specificity of plant-fungal interactions means that the identities of fungi that survive fires could have functional implications for the rate and trajectory of forest recovery and its 
associated C storage. Moreover, decomposition rates are often related to factors that drive microbial community structure and activity, such as fire severity, fire frequency, pre-fire stand type (leading to different litter types), and temperature (Zhang et al., 2008; Prescott, 2010; Treseder et al., 2014; Aaltonen et al., 2019) but their relative importance in field settings is poorly understood.

An unprecedentedly large fire event in the Northwest Territories (NWT), Canada provided an opportunity to evaluate the role of fire in structuring fungal communities and their functions. In 2014, 2.85 Mha of boreal forest in the NWT burned (Walker et al., 2018a), the largest annual area burned in the NWT since records began in 1965 (Canadian Interagency Forest Fire Centre, 2014). In the year immediately following fire, we conducted DNA sequencing on soils from 47 plots that were dominated by conifers before the fire, and found that fire severity altered fungal community composition and caused declines in fungal taxon richness (Day et al., 2019). In this study, we build on this work to assess the distribution of heat-resistant soil fungi across the burned landscape and understand their functions in relation to decomposition and tree seedling growth. We isolated and identified heat-resistant fungi from soils and inoculated litter of conifer and deciduous species with these fungal isolates in biochamber studies to assess their potential to function as saprotrophs. We also tested the effects of heat-resistant fungal taxa on seedling growth, either positive or negative, to assess their potential functions as endophytes or plant pathogens. We did a decomposition experiment with conifer and deciduous litter over 24 mos. in the field at 30 of the 47 plots that varied in pre-fire species composition and fire history. We also identified and counted all tree seedlings that had regenerated 1 year after the fire in all 47 plots.

We asked:

(1) How are heat-resistant fungi distributed across the landscape after fire? We hypothesized that such fungi would be relatively more abundant in areas that experienced fire more recently because there has been less opportunity for succession away from these heat-adapted taxa. Heatresistant fungi may increase with increased fire severity because soil combustion may expose dormant structures in deeper soil layers and heat may promote spore germination after fire;

(2) How do heat-resistant fungi impact decomposition and plant growth of coniferous and deciduous tree seedlings? Our hypothesis was that most heat-resistant fungi would be saprotrophs because these are common after fire in boreal forests in high throughput sequencing studies (e.g., Sun et al., 2015; Day et al., 2019). Saprotrophic activity would be evidenced by decomposition (mass lost) when inoculated with heat-resistant fungi on litter under controlled conditions. Since fungi are key for forest regeneration after fires, we further hypothesized that many heat-resistant fungi would promote growth of tree seedlings under controlled conditions, even if they were not specifically mycorrhizal;
(3) How does spatial variation in abiotic factors and heatresistant fungi contribute to decomposition rates and seedling densities in the field? Our hypothesis was that deciduous (birch) litter would decompose faster than coniferous (black spruce) litter, and that spatial variation in mean annual temperature would be the best predictor of decomposition rates for both species (Cornwell et al., 2008; Zhang et al., 2008). Since we expected many heatresistant fungi to be saprotrophs (Q2), we hypothesized that litter decomposition rates of both tree species would be faster where these were more abundant. In contrast, we expected seedling densities to be more related to other aspects of the fungal community, such as total richness or ectomycorrhizal richness.

\section{METHODS}

\section{Study Area}

This study spanned across the Taiga Plains ecozone in the Northwest Territories (NWT), Canada. The Taiga Plains is a mix of undulating glacial till and peatlands with permafrost in wetter areas (Ecosystem Classification Group, 2009). It is characterized by open, slow-growing forest dominated by black spruce [Picea mariana (Mill) BSP] and/or jack pine (Pinus banksiana Lamb.) with birch (Betula papyrifera Marsh./B. neoalaskana Sargent, J. Arnold Arbor) and trembling aspen (Populus tremuloides Michx.) in well-drained areas. All sample locations are within the discontinuous permafrost zone (Zhang et al., 1999), and in the Low Subarctic ecoregion (Ecosystem Classification Group, 2009). Mean annual temperatures in Hay River $\left(60.82^{\circ} \mathrm{N}\right.$, $\left.-115.79^{\circ} \mathrm{W}\right)$ and Yellowknife $\left(62.45^{\circ} \mathrm{N},-114.37^{\circ} \mathrm{W}\right)$ are -2.5 and $-4.3^{\circ} \mathrm{C}$, respectively. Mean annual precipitation in Hay River and Yellowknife is 336 and $228 \mathrm{~mm}$, respectively (19812010; Environment and Climate Change Canada, 2018).

\section{Field Methods}

This study draws upon an extensive set of research sites that were established to understand the impact of fires throughout the NWT in the years immediately following the 2014 fires. A total of 221 permanent sampling plots were established across gradients of pre-fire landcover, moisture class (site drainage) and fire characteristics, described in Walker et al. (2018a,b); Walker et al. (2019); this study focuses on a subset of these plots on the Taiga Plains. Each plot comprised two parallel $30 \mathrm{~m}$ transects spaced $2 \mathrm{~m}$ apart $\left(60 \mathrm{~m}^{2}\right)$, running due north. All seedlings were identified and counted in $1 \times 1 \mathrm{~m}$ quadrats at 0,12 , and $24 \mathrm{~m}$ along the east transect line in June-August 2015.

To assess fire severity, burn depth, pre-fire soil organic layer (SOL) thickness, and proportion SOL combusted were estimated from measurements in the 2014 burned plots combined with calibrations from other plots in the NWT that had not burned since 1965 (Walker et al., 2018b). Briefly, we measured SOL depth at 10-20 points in both unburned and burned plots. In plots with black spruce, burn depth was estimated as the height of adventitious roots above the residual SOL (Boby et al., 2010) on 10 trees per plot plus an offset $(\sim 3 \mathrm{~cm})$ based on the depth 
of adventitious roots from the green moss surface measured in unburned stands (Walker et al., 2018b). Pre-fire SOL in black spruce stands was calculated by summing the depth of the residual SOL thickness and burn depth. In plots where only jack pine was present, burn depth was based on moisture class-specific estimates of residual SOL thickness compared to SOL depth in unburned plots. Pre-fire SOL thickness in jack pine forests was calculated by summing residual SOL and burn depth. Our metric of fire severity was the proportion of SOL combusted, which was calculated as burn depth/pre-fire SOL thickness (Walker et al., 2018b).

We identified and counted every tree in the $60 \mathrm{~m}^{2}$ plots to assess pre-fire stand composition, including fallen trees killed by fire. Black spruce was the dominant tree species in these forests and stand type was characterized as the proportion of black spruce stems within the plot. This pre-fire stand type metric represents a gradient of black spruce to jack pine.

To estimate the time after last fire prior to 2014 at each plot, we collected basal tree discs or cores just above the root collar of five trees of each dominant conifer representing the dominant size class in each plot. Samples were sanded with progressively finer grits then scanned and rings were counted in Cybis CooRecorder v.7.8 (Larsson, 2006) or WinDendro 2009 (Regent Instruments Canada Inc. 2009). The rapid germination of tree seedlings postfire (Greene and Johnson, 1999) means that these tree ages can be used to reliably estimate the time after last fire in boreal forests. In most cases, tree ages within plots were clearly structured by recruitment cohorts and clustered within 20 years of each other (see Walker et al., 2018b for details). These data are available online (Walker et al., 2018c).

\section{Soil Fungal Communities}

At 47 plots ( 39 plots that burned in 2014 and eight plots in mature forests that did not burn in 2014), soil fungal communities were assessed using high throughput sequencing (Illumina MiSeq; Figure 1; Day et al., 2019). Plots were chosen to represent a range of environmental and fire conditions in terms of stand type, fire severity, and stand age (Table S1). The methods and description of these fungal communities are fully described in Day et al. (2019). Briefly, the top $5 \mathrm{~cm}$ soil was collected for analysis of fungal communities adjacent to quadrats at 0,12 , and $24 \mathrm{~m}$ along the east transect for a total of 141 samples $(47$ plots $\times 3$ samples per plot). DNA was extracted and information on the full fungal communities was assessed using Illumina (MiSeq: ITS 1 region, primers ITS1F and ITS2). Sequencing and bioinformatics processing was performed by McGill University and Génome Québec Innovation Center (Montreal, QC, Canada). A total of $13,424,680$ paired-end reads passed the control quality steps and were assembled. Reads were clustered at $97 \%$ similarity to obtain operational taxonomic units (OTUs). We removed three samples with very low reads $(<5,000$ sequences) and rare OTUs that occurred in two or fewer of these 138 samples, and rarefied to 4,300 reads per sample. The resulting dataset had 138 samples with a mean of 42,999 OTUs per sample (range 62627). Sequences were deposited to DDBJ/ENA/GenBank under the BioSample SAMN09289836 of BioProject PRJNA447993.

\section{Isolation and Identification of Heat-Resistant Fungi From Soils}

Of the 47 plots sampled for DNA sequencing, 12 plots representing different moisture classes were chosen to isolate heat-resistant fungi via culturing (xeric: three plots; subxeric: one plot; mesic-subxeric: four plots; mesic: three plots; mesicsubhygric: one plot; Figure S1). Soil samples were transported on ice to the University of Guelph and processed within $1 \mathrm{wk}$ of collection. Heat-resistant fungi were cultured from soil samples (top $5 \mathrm{~cm}$ ) following standard methods (Nguyen and Seifert, 2008). Soil samples were subjected to heat for $45 \mathrm{~min}$ in an $80^{\circ} \mathrm{C}$ water bath, inverting every $10 \mathrm{~min}$ to distribute heat, then cooled at room temperature for $30 \mathrm{~min}$. Under aseptic conditions, 1,000 $\mu \mathrm{l}$ of the soil solution was mixed with $100 \mathrm{ml}$ half-strength potato dextrose agar with $4 \mathrm{mg}$ chloramphenicol (PDA-C; Oxoid Ltd., Thermo Fisher Scientific, Basingstoke, England), then poured into Petri plates. Plates were sealed with parafilm and incubated upright at room temperature in the dark. Cultures that grew were isolated into pure culture over 2 wks.

Fungal isolates were identified to taxa using a combination of DNA sequencing and morphological assessments. We initially categorized each isolate into morphotypes based on macroscopic characteristics such as shape and color. One fungal isolate from each morphotype was cultured in PDA-C for DNA extraction using the Macherey-Nagel Nuceleospin Mini kit using CTAB lysis buffer (Macherey-Nagel and Co. KG, Düren, Germany). Extracted DNA from each representative morphotype was amplified by PCR (primers ITS5 and ITS4). The PCR mix was composed of $500 \mathrm{nM}$ of each primer, $4 \mu \mathrm{l} 5 \mathrm{X}$ buffer $25 \mathrm{mM}$ magnesium chloride, $200 \mathrm{nM}$ dinucletotide triphosphate mix, 1.25 units of GoTaq Flexi polymerase enzyme (Promega, Madison, WI, USA), and $1 \mu$ l fungal template DNA. Total volume of the mix was made up to $20 \mu \mathrm{l}$ with sterile DNase free water. The PCR program consisted of an initial cycle of DNA denaturation at $95^{\circ} \mathrm{C}$ for $10 \mathrm{~min}$, followed by 35 cycles of $95^{\circ} \mathrm{C}$ for $15 \mathrm{~s}$, annealing at $49.5^{\circ} \mathrm{C}$ for $30 \mathrm{~s}$, elongation at $72^{\circ} \mathrm{C}$ for $90 \mathrm{~s}$, followed by a $7 \mathrm{~min}$ elongation at $72^{\circ} \mathrm{C}$. PCR products were purified using the GenElute PCR Clean-Up Kit (Sigma-Aldrich, Saint Louis, MO, USA) and sequenced by Sanger sequencing at the Genomics Facility in the Advanced Analysis Center at the University of Guelph (http://www.uoguelph.ca/ genomics/).

We entered sequences into the BLAST tool to find closely related sequences in GenBank (http://blast.ncbi.nlm.nih.gov/ Blast.cgi). Identifications from GenBank were verified to genus or species using microscopy for all sequenced and unsequenced isolates of each morphotype. Voucher specimens of each isolate are available in long-term culture collections at the University of Guelph (K. E. Dunfield) and the Canadian Collection of Fungal Cultures (DAOMC 251855-251868). Sequences have been deposited in GenBank (MN410597-MN410606). Of the isolates, seven heat-resistant fungal taxa were identified (see section Results). In some cases, multiple isolates that were thought to be different morphotypes according to macroscopic characteristics were determined to be the same fungal species from sequences. Specifically, three isolates thought to be different morphotypes were identified as Penicillium fuscum from sequences and five isolates thought to different morphotypes 


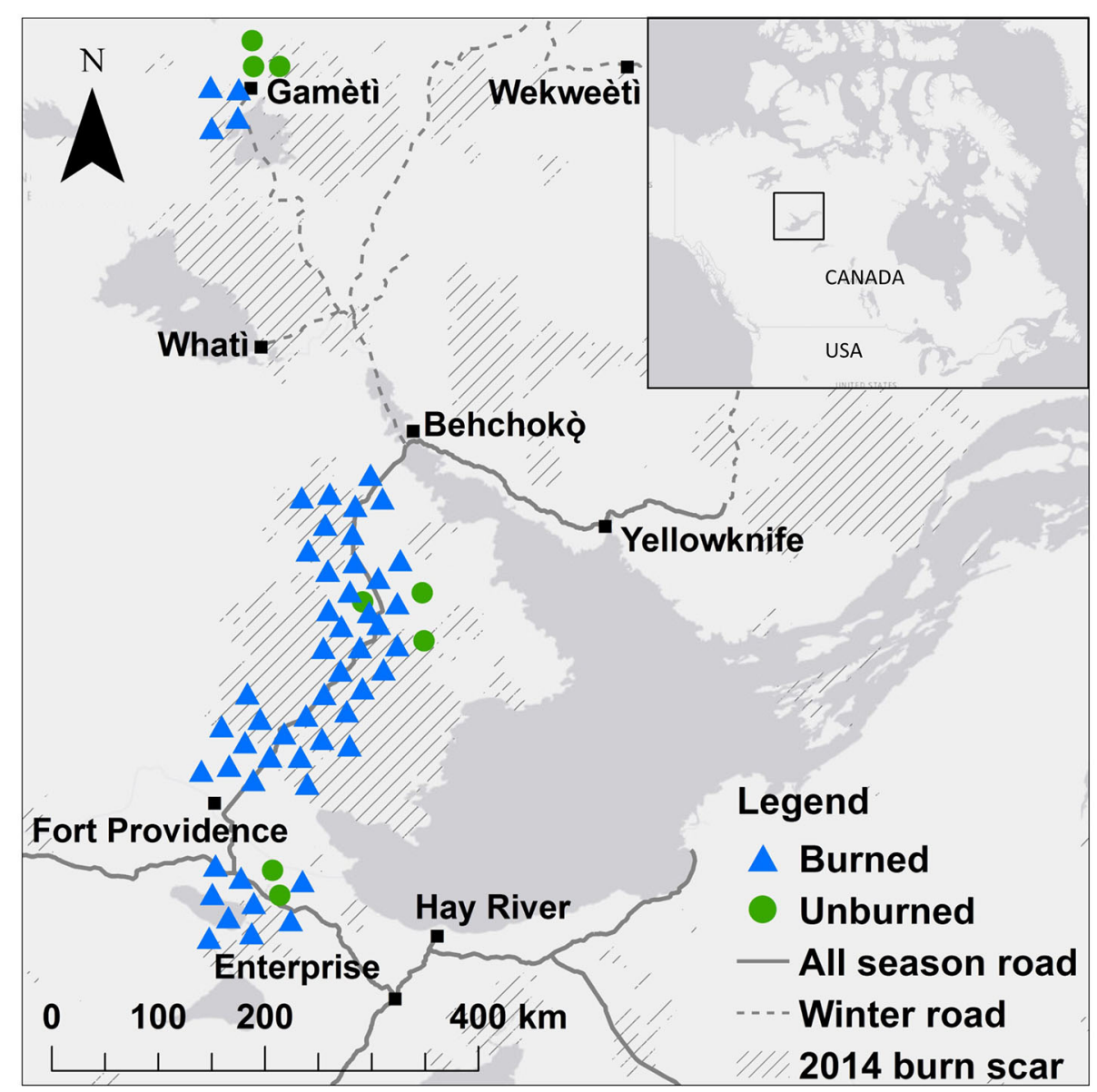

FIGURE 1 | Location of 47 plots where soil samples were collected for analysis of soil fungal communities (Illumina MiSeq) and seedlings were counted 1 year after fire in boreal forest stands of black spruce and jack pine on the Taiga Plains in the Northwest Territories, Canada. Blue triangles show plots that burned in 2014 , green circles show plots that did not burn in 2014 (unburned). Hashed areas show 2014 burn scars and dark gray areas represent water bodies. Points are jittered to reduce overlap but were at least $100 \mathrm{~m}$ from the road. There were three quadrats at each plot.

were identified as $P$. turbatum. Since morphologically similar fungi can have different sequence identities or functions and we did not sequence all isolates, our fungal identities may be considered the minimum that were actually present.

\section{Incubation Study: Saprotrophic Activity of Heat-Resistant Fungi}

We did an incubation study to assess the saprotrophic activity of each of the seven heat-resistant fungal taxa on a conifer (black spruce) and a deciduous (birch) species. Senescing leaves of black spruce were collected from multiple locations across the Taiga Plains in the NWT in late July 2016 by vigorously shaking and rubbing branches of live trees. Senescing leaves of birch were collected by picking yellow or brown senescent leaves from trees or leaves that had obviously recently fallen to the ground in midAugust. Litter was dried at $60^{\circ} \mathrm{C}$ for $3 \mathrm{~d}$ after discarding those with signs of disease or herbivory and shipped in paper bags to Wilfrid Laurier University.

The experimental design was fully factorial with 10 replicates per plant-fungal taxa combination, including a control. There were eight fungal treatments: Coniochaeta sp., Fayodia gracilipes, Leotiomycetes sp., Penicillium turbatum, P. fuscum, P. arenicola, $P$. spinulosum, and a control treatment for a total of 160 experimental units. One fungal isolate of each species was used for all fungal inoculation experiments due to growth chamber space limiting our ability to test all isolates, meaning that we do not have data on within-fungal taxa variation in function. Litter was autoclaved in bags for $75 \mathrm{~min}$ at $121^{\circ} \mathrm{C}$ and then placed in a drying oven at $55^{\circ} \mathrm{C}$ for $3 \mathrm{~d}$. For each species, $400 \mathrm{mg}$ of litter were weighed into $7 \times 7 \mathrm{~cm}$ nylon mesh litterbags $(500 \mu \mathrm{m})$; the birch leaves, including petioles, were roughly cut into $2-5 \mathrm{~cm}$ pieces with flame-sterilized scissors to fit into litterbags. After filling, litterbags were again autoclaved for $20 \mathrm{~min}$ and stored covered at room temperature overnight. One isolate of each heat-resistant fungal taxa had been cultured in the dark at room temperature for $\sim 3$ wks on PDA-C. Under aseptic conditions, fungal cultures were cut into $5 \mathrm{~mm}$ square pieces and five pieces of fungi from the growing edge were placed into each bag. The control treatment consisted of pieces of PDA-C from uninoculated plates. Each litterbag was put into a bleach-disinfected container, rinsed with 
autoclaved deionised water with moistened sterile sand, and covered with a perforated lid, following methods from studies with comparable aims (Day and Currah, 2011; Foudyl-Bey et al., 2016). Containers were placed in an incubator in darkness at $23^{\circ} \mathrm{C}$ and $60 \%$ humidity. Containers were randomized at the beginning and again 5 wks into the $10 \mathrm{wk}$ experiment. At the end of the experiment, litter was removed from litterbags, dried at $60^{\circ} \mathrm{C}$ for $5 \mathrm{~d}$, and weighed.

\section{Seedling Growth Effects of Heat-Resistant Fungi}

To test the effects of heat-resistant fungi on seedling growth, we did a growth chamber trial with black spruce, jack pine, and birch. Efforts to germinate trembling aspen were unsuccessful so this species was excluded. Seeds were collected throughout the Taiga Plains in 2015 and stored in airtight containers at $4^{\circ} \mathrm{C}$. Seeds were germinated in 50:50 sterile soil:sand mix for 4 wks in a growth chamber with $20 / 4 \mathrm{~h}$ of day/night at $21 / 18^{\circ} \mathrm{C}$. Trials showed that surface-disinfecting seeds resulted in low germination rates, so seeds were not treated prior to germination.

We implemented a fully factorial growth chamber experiment, with 10 replicates per plant-fungus combination: Coniochaeta sp., Fayodia gracilipes, Leotiomycetes sp., Penicillium turbatum, P. fuscum, $P$. arenicola, $P$. spinulosum, and a control treatment for a total of 240 experimental units. Each unit was a Conetainer ${ }^{\mathrm{TM}}$ (Stuewe and Sons, Oregon, USA). Sieved soil from burned areas in the NWT was autoclaved twice and rested for $1 \mathrm{wk}$ to allow off-gassing. Conetainers ${ }^{\mathrm{TM}}$ were bleach-disinfected, rinsed, and partially filled with a 1:1 homogenized mix of sand and soil. Heatresistant fungi were cultured in the dark at room temperature for 3 wks on PDA-C. Under aseptic conditions, fungal cultures were cut into $5 \mathrm{~mm}$ square pieces and five pieces of fungi from the growing edge was placed in each conetainer ${ }^{\mathrm{TM}}$. The control treatment contained pieces of PDA-C from uninoculated plates. One seedling was added to each conetainer ${ }^{\mathrm{TM}}$, covered with a layer of soil and sand mix, and topped with sterile sand. Conetainers ${ }^{\mathrm{TM}}$ were spatially randomized within a growth chamber at the beginning and $5 \mathrm{wks}$ into the $10 \mathrm{wk}$ experiment. Seedlings were watered with reverse-osmosis purified water once a day. At harvest, shoots and roots were separated, dried at $60^{\circ} \mathrm{C}$ for $3 \mathrm{~d}$, and then weighed.

\section{In situ Litter Decomposition Rates}

At 30 plots (Figure S1), we did an in situ litterbag experiment to assess post-fire decomposition rates of two widespread tree species in boreal forests, black spruce and birch, using the same litter as the incubation study described above. These plots were selected to incorporate a range of conditions in stand type (dominated by black spruce, jack pine, or mixed), fire severity, and stand age (Table S1); 17 plots overlapped with where fungal sequencing had been undertaken (described above).

Litterbags $(10 \times 10 \mathrm{~cm})$ were made from nylon mesh $(0.5 \mathrm{~mm})$. For black spruce and birch, $1 \mathrm{~g}$ dried leaves were weighed into individually numbered bags and heat-sealed closed. At the end of August 2016, we placed five litterbags of each species, spaced $5 \mathrm{~m}$ apart, at each of the 30 plots. Bags were placed on the burned soil surface and secured with a peg through a wire loop attached to the bag. Most litterbags were collected 24 mos. after deployment (150 litterbags per species) but at eight plots we deployed additional litterbags collected after 12 mos (40 litterbags per species). Immediately following collection, litterbags were kept on ice and shipped to Wilfrid Laurier University. Bag contents were dried at $60^{\circ} \mathrm{C}$ for $3 \mathrm{~d}$ and then weighed. While our mesh size excluded macrofauna, our in situ decomposition rates necessarily include effects of microfauna or microbes other than fungi.

\section{Data Analyses}

All statistical analyses were conducted in R v.3.6.0 (R Core Development Team, 2019), using packages nlme (Pinheiro et al., 2019), lme4 (Bates et al., 2015), ggeffects (Lüdecke, 2018), DHARMa (Hartig, 2019), lsmeans (Lenth, 2016), and boot (Davison and Hinkley, 1997; Canty and Ripley, 2019). Functions within the "tidyverse" were used for basic data manipulations and graph production (Wickham, 2017), with extensions in egg (Auguie, 2018). R code is provided in Supplementary Material. Data are available in Day et al. (2020).

\section{How Are Heat-Resistant Fungi Distributed Across the Landscape After Fire?}

To understand how the isolated heat-resistant fungal taxa were distributed across the landscape, we combined the Sanger sequences of each heat-resistant fungus with the high throughput sequencing data from 138 quadrats in 47 plots (Day et al., 2019). We put all Sanger sequences from the heat-resistant fungi into one FASTA file and used command "closed_ref” in USEARCH v.10 to perform closed-reference clustering against the MiSeq sequences (Edgar, 2010). Sanger sequences were matched with OTUs from Illumina at $97 \%$ similarity. The distribution across the landscape of each heat-resistant fungal taxon was visualized on a map using ArcGIS.

Correlation tests between richness of total fungi, saprotrophs, and plant pathogens against heat-resistant fungal richness were done at the quadrat and plot scales using the Spearman coefficient due to non-normality. Saprotrophs and plant pathogen OTUs were based on functional assignments from published literature using FUNGuild (Nguyen et al., 2016). We retained OTUs with functions considered "probable" and "highly probable" within guilds and were not assigned to multiple guilds of either plant pathogens (24 OTUs), saprotrophs (217 OTUs), or ectomycorrhizas (152 OTUs). P-values were corrected for multiple tests on the same experimental units using the false discovery rate.

To assess drivers of distributions of heat-resistant fungi, we undertook a generalized linear mixed effects model with the summed number of reads of heat-resistant fungi per sample as the response variable and a random effect for plot (three quadratlevel samples per plot). The model assumed a negative binomial distribution to account for over-dispersion with logarithmic link. We included predictors that we hypothesized would be related to the distributions of heat-resistant fungi: fire severity, stand age, and pre-fire stand type. All predictor variables were pairwise uncorrelated $(r<0.7)$. Predictors were centered and standardized prior to inclusion in the models. 


\section{How Do Heat-Resistant Fungi Impact Decomposition Rates and Plant Growth of Coniferous and Deciduous Tree Seedlings? Decomposition}

To assess saprotrophic activity of the heat-resistant fungi for birch and black spruce litter, we calculated decomposition rate as percent mass lost: (initial dry weight-dry weight at time of collection)/initial dry weight) $\times 100$. This was used as the response in a linear model for each tree species. Fungal taxon was the predictor, comparing decomposition rate of each taxon against that of the uninoculated control treatment. Three experimental units were removed from the birch model due to sand causing large values for dry weights or contamination (one Leotiomycetes, two in the control treatment). Results are presented as the mean percent difference for each fungal treatment from the control treatment, based on 999 bootstrap samples. A post-hoc Tukey-Kramer analysis was used to assess differences in effects between fungal taxa.

\section{Seedling Growth}

To test the effects of heat-resistant fungi on seedling growth, we modeled total dry biomass and root-shoot ratio for each tree species: black spruce, jack pine, and birch. Seedling growth was assessed for each tree species using a linear model with fungal taxon as the predictor, comparing plant growth in each taxon against that of the uninoculated control treatment. Only two of the 10 replicates for the birch-P. turbatum treatment survived, so this was excluded from the analyses. Although 10 replicates of the birch-F. gracilipes treatment survived, a labeling error reduced the number of experimental units to eight. Results are presented as the mean percent difference for each fungal treatment from the control treatment, based on 999 bootstrap samples. $P$-values were corrected and a post-hoc Tukey-Kramer analysis was used as above.

\section{How Does Spatial Variation in Abiotic Factors and Heat-Resistant Fungi Contribute to Decomposition Rates and Seedling Densities in the Field?}

We assessed decomposition rates of black spruce and birch litter by calculating percent mass lost as above. Using the litterbags that were collected at 24 mos. for each species, we modeled drivers of decomposition rates using linear mixed effects models with plot as the random effect. Two and one litterbags were not recovered for black spruce and birch, respectively. Predictors included in the models were fire severity, stand age, stand type, and mean annual temperature. We estimated spatial variation in mean annual temperature for each plot for 2017 from Climate WNA (Wang et al., 2012). All predictor variables were pairwise uncorrelated $(r<0.7)$. Predictors were centered and standardized prior to inclusion in the models. An outlier in birch litter was omitted from this model because the sample was contaminated with sand, making it heavy and leading this point to have high leverage in the model.

To assess how fungal communities impacted in situ litter decomposition rates, we used data from the 17 plots where we had both these pieces of information. Since litterbags were not paired spatially with the samples for sequencing, we used the mean decomposition rate per plot as the response variable. We ran separate models for each predictor at the plot level. Heatresistant fungal relative abundance was the total number of reads of all heat-resistant fungi isolated above. Fungal OTU richness was the total number of all fungal OTUs at the plot. Saprotroph richness was the number of OTUs in this category based on FUNGuild (Nguyen et al., 2016). General linear models were run specifying a gaussian response. One outlying plot with high leverage was removed from all black spruce models. $P$-values were corrected as above.

Since we had fungal sequencing spatially paired with seedling densities $\left(\right.$ per $\mathrm{m}^{2}$ ) in three quadrats at each plot, we used these data to assess how fungal communities corresponded to seedling densities in the field. There were no seedlings in the unburned plots and two samples were removed from the sequencing data due to too few sequences for a total of 115 quadrats in 39 plots. We ran five separate generalized linear mixed effects models, one for each predictor of fungal community structure: heatresistant fungal relative abundance, and fungal OTU richness variables calculated as above except at the quadrat level. Fungal plant pathogen richness and ectomycorrhizal richness were the number of OTUs in each of these categories in each sample, based on FUNGuild (Nguyen et al., 2016). Models were run as a Poisson response and plot was the random effect in each model. We re-ran these models with the response as seedling densities of the dominant conifers black spruce and jack pine. $P$-values were corrected as above.

\section{RESULTS}

\section{How Are Heat-Resistant Fungi Distributed Across the Landscape After Fire?}

We isolated seven unique heat-resistant fungal taxa from soils from burned boreal forest stands in the NWT (Table S2). Six of the seven heat-resistant fungal taxa isolated were in Pezizomycotina, the major subphylum of Ascomycota. The fungal taxa were Fayodia gracilipes, Penicillium arenicola, $P$. fuscum, P. spinulosum, P. turbatum, Coniochaeta sp., which could only be identified to genus, and an isolate in class Leotiomycetes. Penicillium turbatum was the most commonly isolated fungus, isolated from 7/12 plots. Detection of the heat-resistant fungi across the wider plot network showed that at least one of the seven heat-resistant taxa were present in all but four of the 47 plots (Figure 2; Table 1). Taxa that were locally abundant by being present in many quadrats within plots, and in many plots so they were widespread across the landscape: P. fuscum, Leotiomycetes sp., and F. gracilipes. Those that were locally rare by being present in few quadrats within plots and in few plots so they were rare across the landscape were $P$. arenicola, Coniochaeta sp., and particularly $P$. spinulosum that was only detected in one quadrat. $P$. turbatum fell between these two categories, where it was in a moderate number of quadrats and plots.

Spearman rank correlations between heat-resistant fungal richness against richness of total fungi and against saprotrophs 

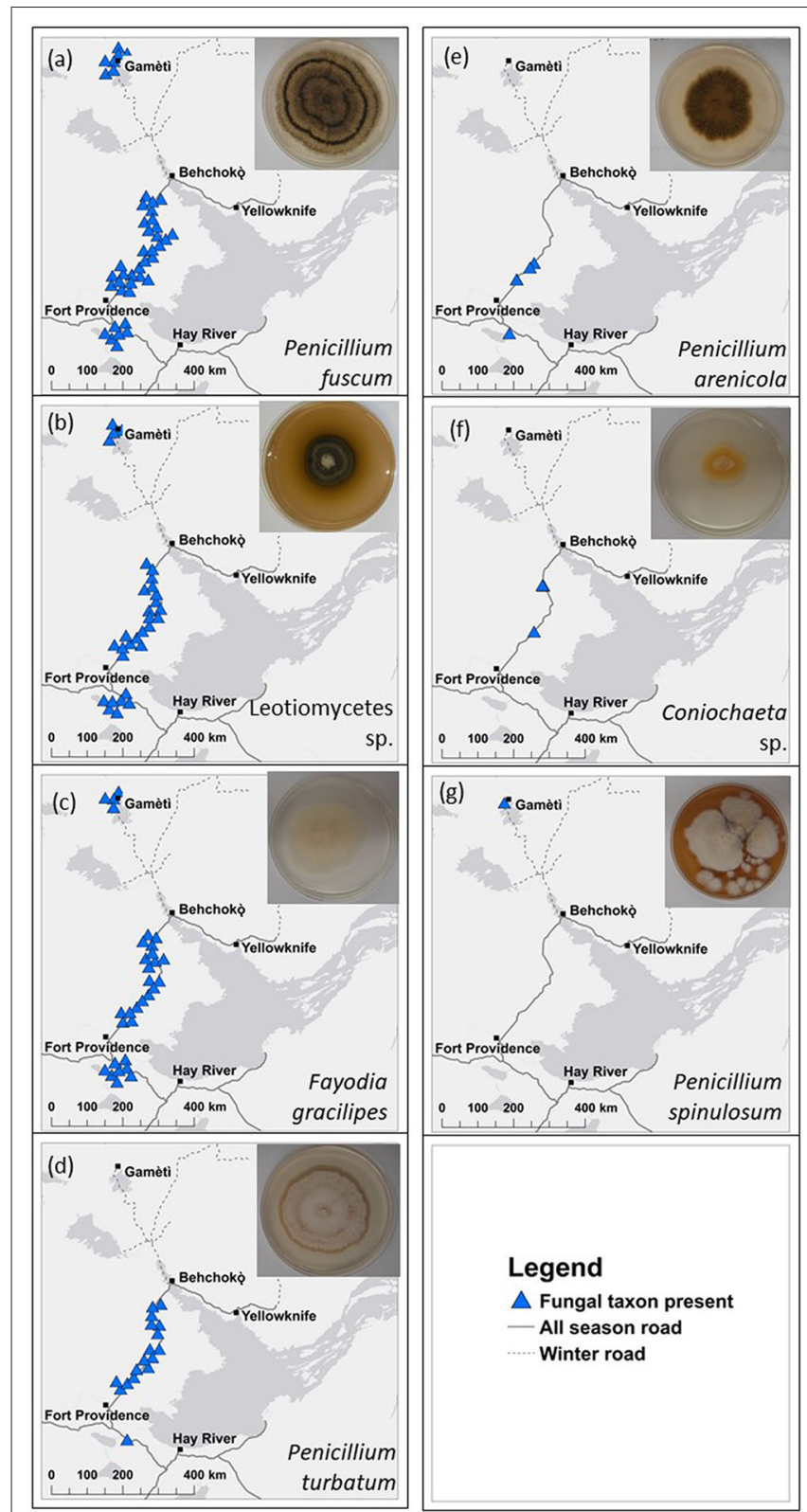

$\triangle$ Fungal taxon present

All season road

Winter road

FIGURE 2 | Map of distributions of seven of heat-resistant fungal taxa across 47 plots in boreal forests in the Northwest Territories, Canada. Blue triangles show locations of (a) Penicillium fuscum, (b) Leotiomycetes sp., (c) Fayodia gracilipes, (d) P. turbatum, (e) P. arenicola, (f) Coniochaeta sp., and (g) $P$. spinulosum. Insets are photos of cultured fungi. Distribution information is based on matching Sanger sequences of the isolated heat-resistant fungal taxa with operational taxonomic units from high throughput sequencing (Illumina, MiSeq) sequences at $97 \%$ similarity. Points are jittered to reduce overlap but were at least $100 \mathrm{~m}$ from the road. All 47 plots are shown in Figure 1. Details of cultures are in Table S2. There were three quadrats at each plot.

were positive and significant at the quadrat scale (Figure S2). There was a positive relationship between plant pathogen richness and heat-resistant fungal richness at the plot scale. The mixed models showed no significant relationships between our $a$

TABLE 1 | Frequencies and relative abundances of heat-resistant fungal taxa across burned boreal forest stands, Northwest Territories, Canada.

\begin{tabular}{lcccc}
\hline Fungal taxon & $\begin{array}{c}\text { Quadrat } \\
\text { frequency } \\
(\boldsymbol{n}=\mathbf{1 3 8})\end{array}$ & $\begin{array}{c}\text { Plot } \\
\text { frequency } \\
(\boldsymbol{n}=\mathbf{4 7})\end{array}$ & $\begin{array}{c}\text { Mean } \\
\text { abundance } \\
\text { per plot } \\
\text { (range) }\end{array}$ & $\begin{array}{c}\text { Plot } \\
\text { frequency in } \\
\text { unburned } \\
(\boldsymbol{n}=\mathbf{8})\end{array}$ \\
\hline Penicillium fuscum & 99 & 43 & $151(0-1086)$ & 8 \\
Fayodia gracilipes & 58 & 31 & $278(0-3309)$ & 4 \\
Leotiomycetes sp. & 49 & 31 & $296(0-3601)$ & 4 \\
P. turbatum & 30 & 17 & $7(0-97)$ & 1 \\
P. arenicola & 6 & 5 & $<1(0-6)$ & 0 \\
Coniochaeta sp. & 3 & 3 & $<1(0-12)$ & 0 \\
P. spinulosum & 1 & 1 & $<1(0-3)$ & 0 \\
\hline
\end{tabular}

Frequency across 138 quadrats in 47 plots, and the mean and range of the relative abundance (number of reads) per plot are shown. Information is based on matching Sanger sequences of the isolated heat-resistant fungal taxa with operational taxonomic units from high throughput sequencing (Illumina, MiSeq) sequences at 47 plots at $97 \%$ similarity. Taxa are presented in declining order of plot frequency.

TABLE 2 | Summary of negative binomial mixed-effects model of relative abundance of seven heat-resistant fungi from 47 plots in boreal forests of the Northwest Territories, Canada.

\begin{tabular}{lcccc}
\hline Predictor & Estimate & SE & $\boldsymbol{Z}$ & $\boldsymbol{P}$ \\
\hline (Intercept) & 4.43 & 0.25 & 17.54 & $<0.001$ \\
Fire severity & 0.00 & 0.25 & -0.02 & 0.985 \\
Stand age & -0.03 & 0.25 & -0.10 & 0.921 \\
Pre-fire stand type & 0.02 & 0.25 & 0.06 & 0.949
\end{tabular}

Plot was the random effect (SD: 1.44). The dispersion parameter was 0.51. SE, standard error of the mean.

priori predictors (stand age, pre-fire stand type, fire severity) and the total relative abundance of heat-resistant fungi (Table 2).

\section{How Do Heat-Resistant Fungi Impact Decomposition and Plant Growth of Coniferous and Deciduous Tree Seedlings? Decomposition}

At the end of the incubation experiment assessing saprotrophic ability of heat-resistant fungi, all taxa except Coniochaeta sp. and Leotiomycetes sp. colonized birch litter, while all taxa except Leotiomycetes sp. colonized black spruce litter (Table S3). On black spruce litter, no fungi showed saprotrophic activity: that is, decomposition rates did not differ between inoculated treatments and the control treatment for this species (Figure 3; Figure S4; Table S4). The Tukey-Kramer post-hoc test showed no significant differences in decomposition rates between fungal taxa (Table S5). On birch litter, F. gracilipes and $P$. arenicola showed significant saprotrophic activity (Figure 3; Table S4). The post-hoc test showed that F. gracilipes caused faster decomposition rates than all other taxa except $P$. arenicola (Table S5). Penicillium arenicola caused faster decomposition rates than $P$. fuscum. Control treatments of both black 


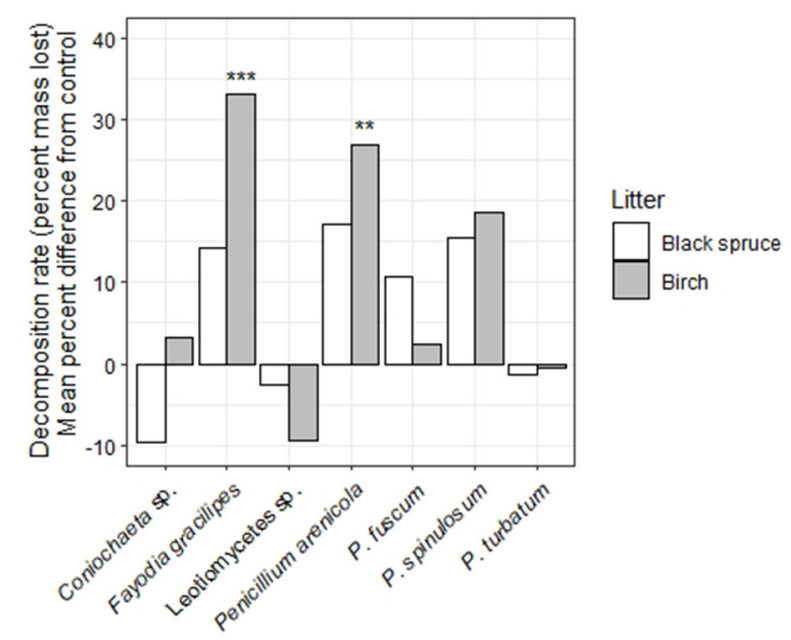

FIGURE 3 | Saprotrophic activity of seven heat-resistant fungal taxa, as measured by decomposition rates measured as mass lost of black spruce (white bars) and birch (gray bars) litter over 10 wks incubation in controlled conditions. Results are presented as the mean percent difference for each fungal treatment from the uninoculated control treatment, from 999 bootstrap samples. Values above zero indicate greater decomposition in inoculated samples relative to the control treatment. Asterisks indicate significant effects of inoculation relative to the control treatment based from linear models ${ }^{\star \star} P<$ $0.01 ;{ }^{* \star} P<0.001$; Table S3).

spruce and birch showed background rates of decomposition (Table S5; Figure S4).

\section{Seedling Growth}

In the seedling growth experiment, black spruce had significantly reduced biomass when inoculated with all fungal taxa except $P$. fuscum and P. spinulosum, relative to the control treatment (Figure 4; Figure S5; Table S6). Seedlings inoculated with either Leotiomycetes sp. or P. fuscum had significantly greater biomass than those inoculated with $P$. turbatum (Table S7). No taxa caused significant differences in root-shoot ratios relative to the control treatment (Table S6). Penicillium arenicola was the only taxon that was recovered from surface disinfected black spruce roots even though it did not exert any significant growth effects on this species (Table S8).

For birch seedlings, $P$. turbatum caused mortality of all but two individuals (Figure S3). Birch seedlings inoculated with $P$. spinulosum had significantly lower biomass relative to the control treatment (Figure 4; Table S6). Seedlings inoculated with either Leotiomycetes sp. or F. gracilipes had significantly greater biomass than those inoculated with P. spinulosum (Table S7). No taxa caused significant differences in root-shoot ratios relative to the control treatment (Table S6). The growth effects of $P$. spinulosum and F. gracilipes occurred even though these taxa were not recovered from surface disinfected birch roots (Table S8).

All seven fungal taxa significantly reduced biomass of jack pine seedlings (Figure 4; Table S6) and there were no amongtaxon differences in their effects (Table S7). No taxa caused significant differences in root-shoot ratios relative to the control treatment (Table S6). Coniochaeta sp., Leotiomycetes sp., $P$. arenicola, and $P$. spinulosum were all recovered from surface disinfected jack pine roots (Table S8).

\section{How Does Spatial Variation in Abiotic Factors and Heat-Resistant Fungi Contribute to Decomposition Rates and Seedling Densities in the Field?}

Birch leaf litter decomposed more rapidly than black spruce in the field at eight plots after 12 mos. ( $t$-test: $t=8.71 ; P<0.001)$ and at 30 plots after $24 \operatorname{mos}(t$-test: $t=18.11 ; P<0.001)$. Birch litter had mean decomposition rate (mass lost) of $35 \%$ of its initial mass (range: 25-44\%) after 12 mos. and 45\% (range: $33-$ $58 \%$ ) after 24 mos. In contrast, the decomposition rate of black spruce was $24 \%$ on average (range: $15-35 \%$ ) after 12 mos. and 34\% (range: 26-55\%) after 24 mos (Figure S6).

Drivers of decomposition rates after 24 mos. differed among species (Figure 5; Table S9). Decomposition of black spruce litter was faster in older plots (those that had a longer firefree interval). Decomposition of birch litter was faster with greater pre-fire proportion of black spruce. In contrast with our hypothesis, spatial variation in mean annual temperature had no significant effect on decomposition rates of either species. The random effect shows that there was high among-plot variation in decomposition rates for both species ( $>2$ SDs; Table S9).

For the models of mean plot in situ decomposition rates as a response in relation to three predictors of fungal community structure (heat-resistant fungal relative abundance, fungal OTU richness, saprotroph richness), no relationships were significant (Table 3). In contrast, for the models for fungal community effects on seedling densities, there was a positive significant relationship between ectomycorrhizal richness and seedling densities of all species and for conifer seedlings (Table 4); this effect was also significant for plant pathogen richness. For conifers, there were significantly fewer seedlings with greater relative abundance of heat-resistant fungi (Table 4). The high variance in the random effect shows there was relatively high among-plot variation ( $>2$ SDs; Table 4).

\section{DISCUSSION}

Knowledge of extremophile distributions and functions can aid understanding of how ecosystems recover under harsh conditions or after severe events. Our study has provided an investigation of the identity, prevalence, and function of heatresistant fungal taxa in recently burned boreal forest stands of the NWT of Canada, and demonstrated their contribution to some aspects of pools of aboveground and belowground C. The incubation study showed that two of the seven heat-resistant fungal taxa could function as saprotrophs, but only on birch and not on black spruce litter. Unexpectedly, all seven isolated heatresistant fungi reduced seedling growth of at least one of birch, black spruce, or jack pine, relative to the uninoculated control treatment. The conifers were particularly negatively affected in the controlled experiments, while in the field there were fewer conifer seedlings with greater abundance of these heat-resistant 

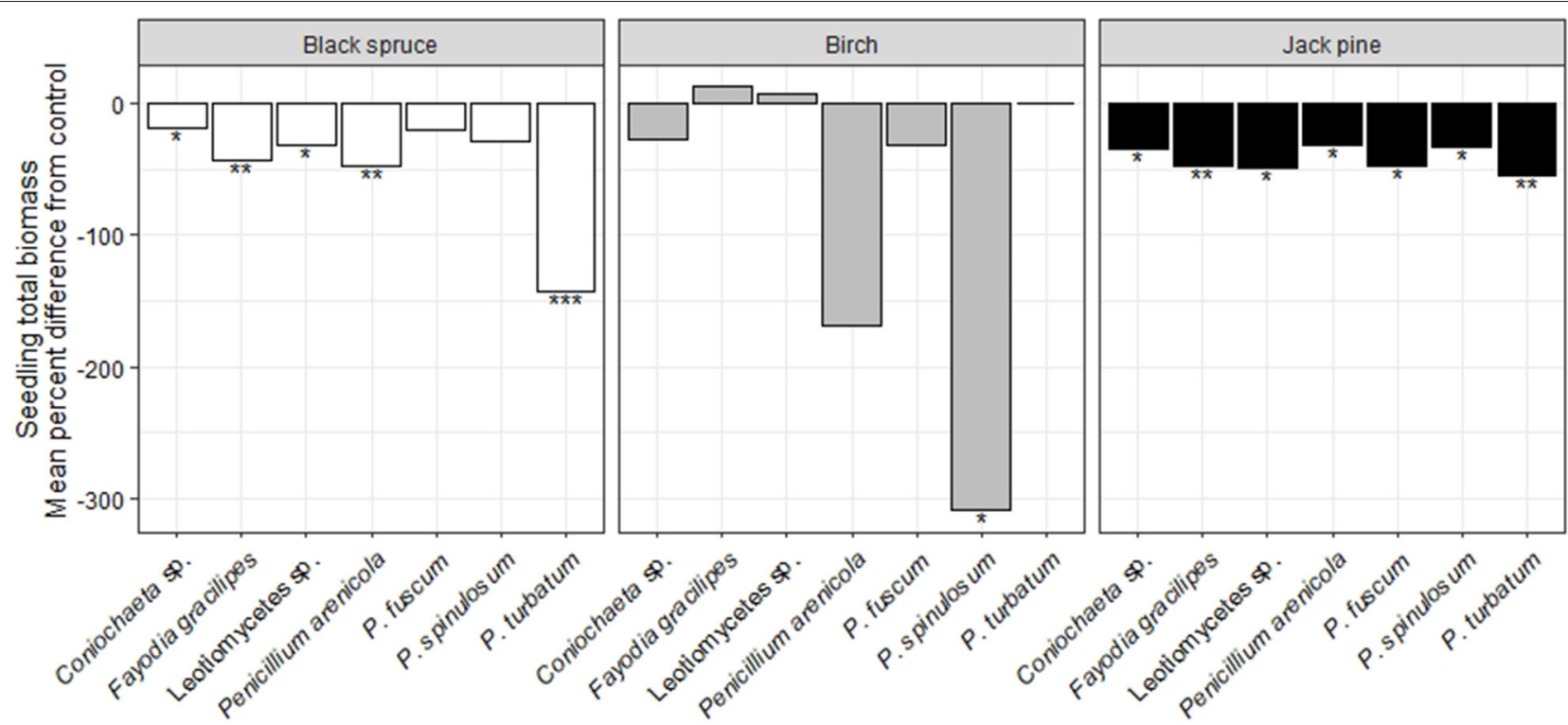

Fungus

FIGURE 4 | Effects of seven heat-resistant fungi on seedling total biomass of black spruce (white bars), birch (gray bars), and jack pine (black bars) in growth chamber experiments over 10 wks. Results are presented as the mean percent difference for each fungal treatment from the uninoculated control treatment, based on 999 bootstraps. Values above zero indicate greater biomass when the fungus was inoculated, relative to the control. Asterisks indicate statistically significant differences relative to the control treatment from linear models $\left({ }^{\star} P<0.05 ;{ }^{\star \star} P<0.01\right.$; ${ }^{\star \star \star} P<0.001$; Table S6).
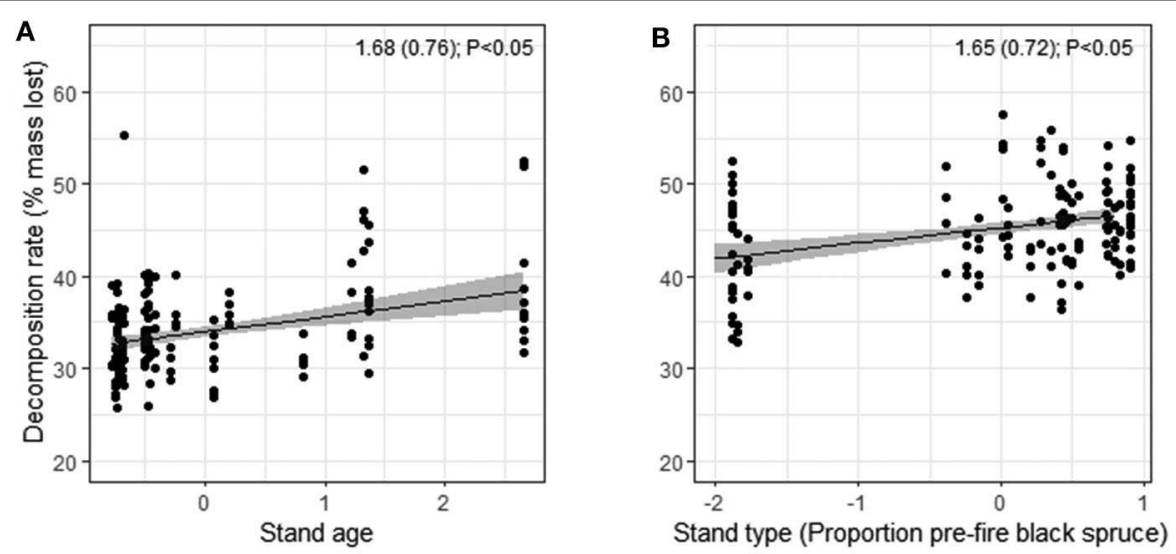

FIGURE 5 | Model-based predictions of in situ decomposition rates of litter of (A) black spruce against stand age, and (B) birch against pre-fire stand type (proportion pre-fire black spruce stems) based on percent mass lost in litterbags over 24 mos. at 30 plots in burned boreal forests, Northwest Territories, Canada. The y-axes show predicted values from linear mixed effects models, with standardized predictors on the x-axes. Estimated coefficients, standard errors, and $P$-values are shown. Full model summaries are reported in Table S9.

fungi. This suggests that fungi can shape forest regeneration after fires and may contribute to declines in conifer regeneration in some situations.

\section{Heat-Resistant Fungal Taxa}

Our sequence of F. gracilipes, the only Basidiomycete cultured, matched $100 \%$ with that isolated from soil in a stand of Picea abies and Populus alba in Russia at $60^{\circ} \mathrm{N}$. This taxon has been isolated as a saprotroph from agricultural soils in Michigan, USA (Thorn et al., 1996). Here, we found F. gracilipes to be locally abundant within plots and widely distributed across the plot network, saprotrophic on birch, and reduced biomass of conifer seedlings. At the other end of the scale, Coniochaeta sp. was rare within plots and across the plot network, reduced conifer seedling biomass, and colonized roots of jack pine and birch. This genus is known to produce antifungal and antibacterial compounds and has been isolated from bogs and fens in Ireland and the USA 
TABLE 3 | Summary of linear models of plot-level in situ litter decomposition against predictors of fungal community structure: heat-resistant fungal relative abundance, fungal operational taxonomic unit (OTU) richness, and saprotroph OTU richness, based on high throughput sequencing at 17 plots in burned boreal forests, Northwest Territories, Canada.

\begin{tabular}{|c|c|c|c|c|c|}
\hline $\begin{array}{l}\text { Litter } \\
\text { species }\end{array}$ & Predictor & Estimate & SE & $T$ & $P$ \\
\hline \multirow{6}{*}{$\begin{array}{l}\text { Black } \\
\text { spruce }\end{array}$} & (Intercept) & 33.76 & 0.58 & 58.46 & $<0.001$ \\
\hline & $\begin{array}{l}\text { Heat-resistant } \\
\text { fungal abundance }\end{array}$ & -0.94 & 0.60 & -1.57 & 0.887 \\
\hline & (Intercept) & 33.76 & 0.62 & 54.35 & $<0.001$ \\
\hline & $\begin{array}{l}\text { Fungal OTU } \\
\text { richness }\end{array}$ & 0.31 & 0.64 & 0.49 & 0.919 \\
\hline & (Intercept) & 33.76 & 0.62 & 54.51 & $<0.001$ \\
\hline & $\begin{array}{l}\text { Saprotroph OTU } \\
\text { richness }\end{array}$ & 0.35 & 0.64 & 0.54 & 0.716 \\
\hline \multirow[t]{6}{*}{ Birch } & (Intercept) & 44.89 & 1.05 & 42.97 & $<0.001$ \\
\hline & $\begin{array}{l}\text { Heat-resistant } \\
\text { fungal abundance }\end{array}$ & -1.17 & 1.08 & -1.09 & 0.441 \\
\hline & (Intercept) & 44.89 & 1.08 & 41.38 & $<0.001$ \\
\hline & $\begin{array}{l}\text { Fungal OTU } \\
\text { richness }\end{array}$ & -0.03 & 1.12 & -0.03 & 0.977 \\
\hline & (Intercept) & 44.89 & 1.08 & 41.37 & $<0.001$ \\
\hline & $\begin{array}{l}\text { Saprotroph OTU } \\
\text { richness }\end{array}$ & 0.05 & 1.12 & 0.04 & 0.977 \\
\hline
\end{tabular}

One outlying plot was removed from all black spruce models. Fungal OTUs were assigned as saprotrophs based on FUNGuild. P-values were corrected for multiple tests on the same experimental units. SE, standard error of the mean.

(Asgari et al., 2007; Thormann and Rice, 2007). The ability of these saprotrophic taxa to colonize roots but not necessarily alter plant biomass demonstrates both the species-specificity involved in plant-fungal interactions and the plasticity of functions of a single fungal taxon (e.g., Smith et al., 2017).

Our sequence of Leotiomycetes matched a species hypothesis in the UNITE database for Leohumicola sp., a genus that has been isolated from soils experiencing regular fires in eastern Canada (Hambleton et al., 2005; Kõljalg et al., 2013). Our results support this as a fire-adapted group that is root-associated, since the Leotiomycetes isolate colonized roots of birch and jack pine but did not colonize litter. However, it significantly reduced biomass of conifer seedlings. Leohumicola spp. contain ericoid mycorrhizas that can survive fires via thick-walled, heat-resistant spores called aleurioconidia (Hambleton et al., 2005; Nguyen and Seifert, 2008). This group may therefore support regeneration of ericoid plants in the understory, such as Vaccinium vitis-idaea, which was commonly resprouting in our plots (White, 2018). These different effects of fungal taxa on plant growth are thought to promote aboveground diversity (Bever et al., 2010).

Penicillium spp. are ecologically diverse and globally ubiquitous, with many known to be heat-resistant (Houbraken and Samson, 2011; Visagie et al., 2014). Members of this genus are common in peatlands and have been frequently isolated from soils in Canadian boreal forests (Summerbell, 2005; De Bellis et al., 2007; Thormann and Rice, 2007). Our sequence for $P$. arenicola closely matched those recovered from soils in
Norman Wells, NWT, and pine forests in Ukraine and Ontario (Peterson et al., 2010). This taxon was sparsely distributed, colonized litter and roots of all taxa, was saprotrophic on birch litter, and reduced biomass of black spruce seedlings. While P. spinulosum is considered a saprotroph, we did not observe this effect in our study. Instead, this taxon colonized roots of jack pine and reduced seedling growth of all three tree species. This was unexpected since $P$. spinulosum is associated with ectomycorrhizal roots of black spruce in Ontario boreal forests (Summerbell, 2005). This taxon was only present in one quadrat at one of our 47 plots. Little is known of P. turbatum in terms of function, but this taxon had the most negative effects on seedlings in terms of both survival and biomass across tree species.

The lack of relationship between the relative abundance of heat-resistant fungi and fire severity, as the proportion of the organic horizon combusted, lends support to our previous speculation that many fungi in these soils survived fires rather than dispersing in after the fires (Day et al., 2019). While fungal propagules close to the soil surface may be susceptible to mortality due to fire, fungi without adaptations to high heat likely survive deeper down (Baar et al., 1999; Certini, 2005; Cairney and Bastias, 2007). This may be particularly important in deep organic soils that provide insulation against high temperatures. Fungi can also survive high temperatures within wood (Carlsson et al., 2012; Kuo et al., 2015) and roots (e.g., Hewitt et al., 2013). Future studies investigating how these mechanisms of survival mediate fungal community structure and function after fire would help us better understand ecosystem recovery after wildfires and the patchiness in local and regional distributions. This would require pre-fire fungal information.

In this study, most of our heat-resistant fungal taxa were either locally infrequent and rare across the plot network across the landscape, or locally abundant within plots and widely distributed across the plot network; these latter taxa were often also in the unburned plots. However, our DNA-based methods do not indicate if these taxa were active. Recent comprehensive work on abundance-occupancy relationships using fungal fruiting bodies revealed that most fungi are rare but also that locally rare fungi can be abundant at larger scales (Gange et al., 2019).

By definition, heat-resistant fungi are those that can survive $75^{\circ} \mathrm{C}$ for at least $30 \mathrm{~min}$ (Nguyen and Seifert, 2008; Samson et al., 2010). It is likely that there are other heat-resistant fungi in our plots but they were not detected due to isolates growing over each other on plates, media selectivity, and presence of unculturable taxa. This may contribute to why we found no significant predictors of heat-resistant fungal abundance across the plots. Our methods were not designed to isolate mycorrhizas so it was not surprising that these were not isolated. Other studies experimentally inferring effects of fire on microbial communities have used temperatures between 45 and $75^{\circ} \mathrm{C}$ (Izzo et al., 2006; Peay et al., 2009), up to $500^{\circ} \mathrm{C}$, where temperatures above $400^{\circ} \mathrm{C}$ resulted in complete fungal mortality (Bárcenas-Moreno and Bååth, 2009). These high temperatures may reflect those at the very surface of soils (Certini, 2005). Nonetheless, our study has shed light on the distribution and ecological functions of extremophile fungi in the environment. 
TABLE 4 | Summary of linear mixed-effect models of quadrat seedling densities (per $\mathrm{m}^{2}$ ) for all species and for conifers only against predictors of fungal community structure: heat-resistant fungal relative abundance, fungal operational taxonomic unit (OTU) richness, pathogen OTU richness, and ectomycorrhizal OTU richness, based on high throughput sequencing in burned boreal forests, Northwest Territories, Canada.

\begin{tabular}{|c|c|c|c|c|c|c|}
\hline & Predictor & Estimate & SE & $t$ & $\boldsymbol{P}$ & Plot SD \\
\hline \multirow[t]{8}{*}{ All seedlings } & Intercept & -0.24 & 0.51 & -0.46 & 0.735 & 2.68 \\
\hline & Heat-resistant fungal abundance & 0.00 & 0.04 & -0.01 & 0.989 & \\
\hline & Intercept & -0.24 & 0.51 & -0.47 & 0.735 & 2.69 \\
\hline & Fungal OTU richness & 0.05 & 0.05 & 1.06 & 0.735 & \\
\hline & Intercept & -0.24 & 0.51 & -0.48 & 0.686 & 2.67 \\
\hline & Pathogen OTU richness & 0.18 & 0.05 & 3.79 & $<0.01$ & \\
\hline & Intercept & -0.24 & 0.51 & -0.48 & 0.686 & 2.68 \\
\hline & Ectomycorrhizal richness & 0.14 & 0.05 & 2.93 & $<0.05$ & \\
\hline \multirow[t]{8}{*}{ Conifer seedlings } & Intercept & -0.31 & 0.49 & -0.64 & 0.550 & 2.58 \\
\hline & Heat-resistant fungal abundance & -0.24 & 0.05 & -4.67 & $<0.001$ & \\
\hline & Intercept & -0.29 & 0.49 & -0.60 & 0.550 & 2.58 \\
\hline & Fungal OTU richness & 0.05 & 0.05 & 0.91 & 0.550 & \\
\hline & Intercept & -0.31 & 0.49 & -0.62 & 0.550 & 2.56 \\
\hline & Pathogen OTU richness & 0.24 & 0.05 & 4.67 & $<0.001$ & \\
\hline & Intercept & -0.30 & 0.49 & -0.60 & 0.550 & 2.58 \\
\hline & Ectomycorrhizal OTU richness & 0.14 & 0.05 & 2.90 & $<0.05$ & \\
\hline
\end{tabular}

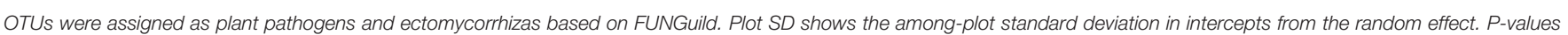
were corrected for multiple tests on the same experimental units. Significant effects $(P<0.05)$ are in bold. SE, standard error of the mean.

\section{Post-fire Fungi Reduced Seedling Biomass and Conifer Seedling Densities}

Our study suggests that functions of extremophile fungi that are present post-fire may not necessarily promote ecosystem recovery in the way we may expect. A surprising result was that all seven heat-resistant fungi significantly reduced biomass of seedlings of at least one tree species relative to the uninoculated control treatment. Many inoculated fungi were not re-isolated from roots of seedlings but still reduced biomass, suggesting indirect effects on plant growth such as nutrient turnover or via secondary metabolites. For example, $P$. spinulosum reduced birch growth but was not recovered from surface-disinfected roots. The conifers were particularly susceptible to negative effects of heat-resistant fungi, and this transferred to the field where there were fewer conifer seedlings with greater abundance of these fungi. Further exploration is warranted on the effect of fungi that may contribute to observed declines in conifer regeneration after wildfires in some boreal forests (Johnstone et al., 2010; Reid, 2017). Future studies could pre-inoculate seedlings with heatresistant fungi where isolated functions have been tested under controlled conditions, such as the ones isolated in our study, and transplant them into the field to better elucidate the roles of these fungi in forest regeneration.

At this stage, we cannot consider these heat-resistant fungal taxa plant pathogens because no seedlings showed disease symptoms and Koch's postulates have not been fulfilled (tests used to verify the identity and cause of pathogenicity). Richness of OTUs considered plant pathogens in FUNGuild were positively related to seedling densities in the field, which highlights the limitations in defining plant-fungal interactions based on taxonomy alone. Our wider sequencing data show a positive relationship between fungi that are considered pathogenic and fire severity (Figure S7), a pattern similarly observed in the Alaskan tundra (Hewitt et al., 2016). This might be expected because pathogens have adaptations to survive adverse conditions or long periods of dormancy without a host (Agrios, 2005) may also confer ability to survive high heat. We need a better understanding of pathogens after fire in natural systems and their role in determining forest regeneration relative to other factors. If high fire severity promotes survival of fungi that reduce plant growth to the point that forest regeneration or plant communities are compromised, this could reduce aboveground $\mathrm{C}$ in terms of plant biomass and impact nutrient cycling.

In the field, the positive effect of ectomycorrhizal richness on seedling densities supports this as an important mutualism for forest regeneration (Grogan et al., 2000; Treseder et al., 2004; Peay et al., 2009). Understanding fungal functions from sequencing alone is complicated by the ability for single fungal isolates to obtain $\mathrm{C}$ in multiple ways and have multiple functions, which may be modified by other microbial interactions in the field (Schäfer et al., 1989; Shah et al., 2016; Smith et al., 2017). While we did not assess differences between isolates of single taxa in our study, our single isolate of $F$. gracilipes was a saprotroph on birch but also reduced growth of black spruce and jack pine. How these multifunctionalities play out in the field is unclear. For example, Neurospora crassa, a well-known and ubiquitous heat-resistant saprotroph, is also capable of endophytic and pathogenic life stages within the same host, Pinus sylvestris (Kuo et al., 2015). Ectomycorrhizas can also be saprotrophs (Shah 
et al., 2016), making them particularly important for $\mathrm{C}$ cycling by decomposing organic matter and influencing aboveground $\mathrm{C}$ stocks by providing nutrients for plant growth.

\section{Implications of Fire-Induced Shifts in Vegetation}

In situ, birch litter decomposed faster where there was greater proportion of pre-fire black spruce. Put another way, birch decomposed better in black spruce-dominated plots relative to jack pine-dominated plots. This pattern could reflect moisture availability, a limiting factor in microbial activity, because black spruce stands have high surface moisture (Figure S8). However, if moisture was the underlying mechanism then we expect a positive relationship for both species, which was not the case (Tables S10, S11). Others suggest that poor drainage and cool conditions reduce decomposition rates in black sprucedominated plots regardless of litter inputs (Preston et al., 2014), which contrasts with our observations in this post-fire environment. A study of mesic boreal forests suggests that litter inputs were more important than climatic differences along a latitudinal gradient for accumulation of soil organic matter (Kohl et al., 2018). This could explain the lack of significance of mean annual temperature in our study. Alternatively, mean annual temperature may not have been a good predictor of decomposition rates because the gridded data were too coarse or low variation in this variable.

Fire-induced shifts from black spruce to deciduous or jack pine dominance are being observed across the NWT (Reid, 2017; Whitman et al., 2018) and North American boreal forests (Johnstone et al., 2010; Boiffin and Munson, 2013; Hart et al., 2019). Shifts from black spruce to jack pine, the dominant shift on the Taiga Plains where our study occurred (Reid, 2017; Whitman et al., 2018), may not alter C pools very much because these conifers have similar litter quality (Preston et al., 2014). However, while shifts toward deciduous dominance may alter litter quality and lead to faster decomposition rates and potentially reduce belowground $\mathrm{C}$, aboveground $\mathrm{C}$ can increase, resulting in overall similar net $\mathrm{C}$ balance but differential distribution (Alexander et al., 2012; Alexander and Mack, 2016). During decomposition, $\mathrm{C}$ can be retained in mineral soil (Prescott, 2010), in undecomposed mycelial networks (Clemmensen et al., 2013), or in soil fauna. Soil warming, which may be enhanced postfire, can alter fungal communities and reduce resource allocation to decomposition activities (Asemaninejad et al., 2017; RomeroOlivares et al., 2019). Thus, the association between decomposers, $\mathrm{CO}_{2}$ or $\mathrm{CH}_{4}$ fluxes, and accumulation of soil organic matter is not always clear (Allison et al., 2010; Kyaschenko et al., 2017). Mycorrhizas can sequester large amounts of $\mathrm{C}$ by transferring C from photosynthate into deep soil layers (Clemmensen et al., 2013 , 2015). Fire-induced plant mortality and long-term changes in mycorrhizal communities could therefore have greater relative importance for driving $\mathrm{C}$ dynamics than changes in saprotrophs or surface decomposition.

\section{Black Spruce Decomposed Faster in Stands With Longer Fire-Free Intervals}

The positive relationship observed between stand age and in situ black spruce decomposition rates could reflect recovery or succession of microbial community function over time (Holden et al., 2013; Clemmensen et al., 2015; Sun et al., 2015). Our previous work showed detectable differences in fungal community composition in different stand ages at these plots, even after fire (Day et al., 2019). The present study showed no relationship between stand age and heat-resistant fungi, but as mentioned above we likely did not isolate all heat-resistant fungi that were present. Although none of the heat-resistant fungi were saprotrophic on black spruce in the incubation study, black spruce litter decomposed faster in the field where these fungi were more abundant. These results may seem counterintuitive but the decomposition rates encompass effects of all organisms able to enter litterbags, including fungi, bacteria, and microfauna. While we autoclaved the litter to sterilize it in the incubation study to be able to clearly assess the effect of the inoculated fungi, this increased the C:N ratio of both species (Table S12). Other sterilization techniques that have less impact on the chemical composition of litter could be considered for future studies. While it is unfortunate that we had background decomposition in the uninoculated control treatment, we can assume that all treatments experienced this background level so our experiment showed that some fungi were able to decompose above that of the background level.

Heat-resistant fungi may decline with time since fire, as has been observed in Rhizopogon olivaceotinctus in California, which fills a short-term disturbance niche after fire (Peay et al., 2009; Glassman et al., 2016). Fungal succession may be inhibited as fire frequency increases, which could lead to greater prevalence or dominance of heat-resistant fungi over the long term. Information on pre-fire fungal communities would help us better understand changes in heat-resistant fungi with changes in fire frequency, which is seldom available (Glassman et al., 2016). Pre-fire data would also facilitate being able to partition fungi that survived fire from those that dispersed in after fire.

\section{CONCLUSION}

Our study provides information on the distribution and function of extremophile heat-resistant fungi in a fire-adapted forested ecosystem. We investigated how fire impacts soil fungi and the potential implications for accumulation of $\mathrm{C}$ via decomposition and tree seedling growth. We found the distribution of heatresistant fungi after fires are commonly locally abundant and widely distributed, including in unburned areas, or locally rare and sparse across the landscape. All heat-resistant fungi reduced biomass of seedlings of at least one tree species in controlled experiments. Lower conifer seedling densities where heat-resistant fungi were more abundant in the field suggests that these fungi may play a role in structuring plant communities after fire by reducing conifer regeneration. The greater in situ decomposition rates of black spruce litter in stands with longer fire-free intervals suggests this is linked to recovery or succession of microbial communities of the NWT. While DNA sequencing studies provide a useful overview of microbial community structure, understanding functional consequences of fire on fungal communities can aid predictions of decomposition and plant growth, and aboveground and belowground $\mathrm{C}$ sequestration as fire activity increases in many regions. 


\section{DATA AVAILABILITY STATEMENT}

The datasets generated for this study can be found in the DDBJ/ENA/GenBank under the BioSample SAMN09289836 of BioProject PRJNA447993; Genbank (MN410597-MN410606); Canadian Collection of Fungal Cultures (DAOMC 251855 251868); A subset of the data are available in Walker et al. (2018c). Remaining data are available in Day et al. (2020).

\section{AUTHOR CONTRIBUTIONS}

ND and JB conceived the study. ND, SC, JJ, MM, MT, and XW designed field sampling. ND, KR, and XW collected field samples and data. ND undertook all lab work and experiments, and data analyses. ND wrote the first draft of the manuscript. All authors edited the manuscript.

\section{FUNDING}

This article is part of Project 170 of the Government of the Northwest Territories (GNWT) Department of Environment and Natural Resources Cumulative Impacts Monitoring Program (JB, JJ, and SC). Additional funding for this research was provided by a Natural Science and Engineering Research Council (NSERC) Post-doctoral Fellowship (ND), NSERC Changing Cold Regions Network, Northern Scientific Training Program,

\section{REFERENCES}

Aaltonen, H., Palviainen, M., Zhou, X., Köster, E., Berninger, F., Pumpanen, J., et al. (2019). Temperature sensitivity of soil organic matter decomposition after forest fire in Canadian permafrost region. J. Environ. Manage. 241, 637-644. doi: 10.1016/j.jenvman.2019.02.130

Agrios, G. N. (2005). Plant Pathology, 5th Edn. Burlington: Elsevier.

Alexander, H. D., and Mack, M. C. (2016). A canopy shift in interior Alaskan boreal forests: consequences for above- and belowground carbon and nitrogen pools during post-fire succession. Ecosystems 19, 98-114. doi: 10.1007/s10021-015-9920-7

Alexander, H. D., Mack, M. C., Goetz, S., Beck, P. S. A., and Belshe, E. F. (2012). Implications of increased deciduous cover on stand structure and aboveground carbon pools of Alaskan boreal forests. Ecosphere 3:45. doi: 10.1890/ES11-00364.1

Allison, S. D., McGuire, K. L., and Treseder, K. K. (2010). Resistance of microbial and soil properties to warming treatment seven years after boreal fire. Soil Biol. Biochem. 42, 1872-1878. doi: 10.1016/j.soilbio.2010.07.011

Andrieux, B., Beguin, J., Bergeron, Y., Grondin, P., and Paré, D. (2018). Drivers of postfire soil organic carbon accumulation in the boreal forest. Glob. Change Biol. 24, 4797-4815. doi: 10.1111/gcb.14365

Asemaninejad, A., Thorn, R. G., and Lindo, Z. (2017). Experimental climate change modifies degradative succession in boreal peatland fungal communities. Microb. Ecol. 73, 521-531. doi: 10.1007/s00248-0160875-9

Asgari, B., Zare, R., and Gams, W. (2007). Coniochaeta ershadii, a new species from Iran, and a key to well-documented Coniochaeta species. Nova Hedw. 84, 175-187. doi: 10.1127/0029-5035/2007/0084-0175

Auguie, B. (2018). Egg: Extensions for "ggplot2", to Align Plots, and Set Panel Sizes. Avaliable online at: https://CRAN.R-project.org/package=egg (accessed December 20, 2017).

Baar, J., Horton, T. R., Kretzer, A. M., and Bruns, T. D. (1999). Mycorrhizal colonization of Pinus muricata from resistant propagules after a
NSERC Discovery (MT), a National Science Foundation DEB RAPID (\#1542150), NASA Arctic Boreal and Vulnerability Experiment (ABoVE) Legacy Carbon grant NNX15AT71A (MM), and CFREF Global Water Futures funding to the Northern Water Futures project.

\section{ACKNOWLEDGMENTS}

In kind support was provided by the Wilfrid Laurier University - GNWT Partnership and the Bonanza Creek LTER program. We thank the Aurora Research Institute (Research License 15879), the Ka'a'gee Tu First Nation, the Tłicho Government, and the Wek'éezhii Renewable Resources Board for support. Sand was graciously donated by Hutcheson Sand and Mixes. We thank H. Nguyen for initial discussions of heat-resistant fungi and advice on isolation methods, A. Sniderhan for making the maps, K. Stevens for microscope use, G. MorenoHagelsieb for bioinformatics assistance, and numerous students and technicians for providing field and lab assistance.

\section{SUPPLEMENTARY MATERIAL}

The Supplementary Material for this article can be found online at: https://www.frontiersin.org/articles/10.3389/ffgc.2020. 00068/full\#supplementary-material stand-replacing wildfire. New Phytol. 143, 409-418. doi: 10.1046/j.14698137.1999.00452.x

Baldrian, P. (2017). Forest microbiome: diversity, complexity and dynamics. FEMS Microbiol. Rev. 41, 109-130. doi: 10.1093/femsre/fuw040

Bárcenas-Moreno, G., and Bååth, E. (2009). Bacterial and fungal growth in soil heated at different temperatures to simulate a range of fire intensities. Soil Biol. Biochem. 41, 2517-2526. doi: 10.1016/j.soilbio.2009.09.010

Bates, D., Maechler, M., Bolker, B., and Walker, S. (2015). Fitting linear mixed-effects models using lme4. J. Stat. Softw. 67, 1-48. doi: 10.18637/jss. v067.i01

Bent, E., Kiekel, P., Brenton, R., and Taylor, D. L. (2011). Root-associated ectomycorrhizal fungi shared by various boreal forest seedlings naturally regenerating after a fire in interior Alaska and correlation of different fungi with host growth responses. App. Environ. Microbiol. 77, 3351-3359. doi: 10.1128/AEM.02575-10

Bever, J. D., Dickie, I. A., Facelli, E., Facelli, J. M., Klironomos, J., Moora, M., et al. (2010). Rooting theories of plant community ecology in microbial interactions. Trends Ecol. Evol. 25, 468-478. doi: 10.1016/j.tree.2010.05.004

Birnbaum, C., Hopkins, A. J. M., Fontaine, J. B., and Enright, N. J. (2019). Soil fungal responses to experimental warming and drying in a Mediterranean shrubland. Sci. Total Environ. 683, 524-536. doi: 10.1016/j.scitotenv.2019.05.222

Boby, L. A., Schuur, E. A., Mack, M. C., Verbyla, D., and Johnstone, J. F. (2010). Quantifying fire severity, carbon, and nitrogen emissions in Alaska's boreal forest. Ecol. Appl. 20, 1633-1647. doi: 10.1890/08-2295.1

Boiffin, J., and Munson, A. D. (2013). Three large fire years threaten resilience of closed crown black spruce forests in eastern Canada. Ecosphere 4:56. doi: 10.1890/ES13-00038.1

Cairney, J. W. G., and Bastias, B. A. (2007). Influences of fire on forest soil fungal communities. Can. J. For. Res. 37, 207-215. doi: 10.1139/x06-190

Canadian Interagency Forest Fire Centre (2014). Situation Report - Sep 22, 2014. Avaliable online at: http://www.ciffc.ca/firewire/current.php?lang=en\&date= 20140922 (accessed December 20, 2017) 
Canty, A., and Ripley, B. D. (2019). boot: Bootstrap R (S-Plus) Functions. R package version 1.3-22. Available online at: https://cran.r-project.org/web/packages/ boot/index.html (accessed October 24, 2019).

Carlsson, F., Edman, M., Holm, S., Eriksson, A.-M., and Jonsson, B. G. (2012). Increased heat resistance in mycelia from wood fungi prevalent in forests characterized by fire: a possible adaptation to forest fire. Fungal Biol. 116, 1025-1031. doi: 10.1016/j.funbio.2012.07.005

Certini, G. (2005). Effects of fire on properties of forest soils: a review. Oecologia 143, 1-10. doi: 10.1007/s00442-004-1788-8

Clemmensen, K. E., Bahr, A., Ovaskainen, O., Dahlberg, A., Ekblad, A., Wallander, H., et al. (2013). Roots and associated fungi drive longterm carbon sequestration in boreal forest. Science 339, 1615-1618. doi: $10.1126 /$ science. 1231923

Clemmensen, K. E., Finlay, R. D., Dahlberg, A., Stenlid, J., Wardle, D. A., and Lindahl, B. D. (2015). Carbon sequestration is related to mycorrhizal fungal community shifts during long-term succession in boreal forests. New Phytol. 205, 1525-1536. doi: 10.1111/nph.13208

Coops, N. C., Hermosilla, T., Wulder, M. A., White, J. C., and Bolton, D. K. (2018). A thirty year, fine-scale, characterization of area burned in Canadian forests shows evidence of regionally increasing trends in the last decade. PLoS ONE 13:e0197218. doi: 10.1371/journal.pone.0197218

Cornwell, W. K., Cornelissen, J. H. C., Amatangelo, K., Dorrepaal, E., Eviner, V. T., Godoy, O., et al. (2008). Plant species traits are the predominant control on litter decomposition rates within biomes worldwide. Ecol. Lett. 11, 1065-1071. doi: 10.1111/j.1461-0248.2008.01219.x

Dahlberg, A. (2002). Effects of fire on ectomycorrhizal fungi in Fennoscandian boreal forests. Silva Fenn. 36, 69-80. doi: 10.14214/sf.551

Davison, A. C., and Hinkley, D. V. (1997). Bootstrap Methods and Their Applications. (Cambridge: Cambridge University Press). doi: 10.1017/CBO9780511802843

Day, M. J., and Currah, R. S. (2011). In vitro degradation of the moss Hylocomium splendens by three pleosporalean fungi. Can. J. Microbiol. 57, 382-391. doi: 10.1139/w11-024

Day, N. J., Dunfield, K. E., Johnstone, J. F., Mack, M. C., Turetsky, M. R., Walker, X. J., et al. (2019). Wildfire severity reduces richness and alters composition of soil fungal communities in boreal forests of western Canada. Glob. Chang. Biol. 25, 2310-2324. doi: 10.1111/gcb.14641

Day, N. J., Cumming, S. G., Dunfield, K. E., Johnstone, J. F., Mack, M. C., Reid, K. A., et al. (2020). Identifying functional impacts of heat-resistant fungi on boreal forest recovery after wildfire. doi: 10.5061/dryad.6q573n5wf

De Bellis, T., Kernaghan, G., and Widden, P. (2007). Plant community influences on soil microfungal assemblages in boreal mixed-wood forests. Mycologia 99, 356-367. doi: 10.1080/15572536.2007.11832560

Duhamel, M., Wan, J., Bogar, L. M., Segnitz, R. M., Duncritts, N. C., and Peay, K. G. (2019). Plant selection initiates alternative successional trajectories in the soil microbial community after disturbance. Ecol. Monogr. 89:e01367. doi: $10.1002 /$ ecm. 1367

Ecosystem Classification Group (2009). Ecological Regions of the Northwest Territories - Taiga Plains. Yellowknife: Department of Environment and Natural Resources, Government of the Northwest Territories.

Edgar, R. C. (2010). Search and clustering orders of magnitude faster than BLAST. Bioinformatics 26, 2460-2461. doi: 10.1093/bioinformatics/btq461

Environment and Climate Change Canada (2018). Avaliable online at: http:// climate.weather.gc.ca/climate_normals/index_e.html (accessed February 5, 2018).

Fenton, N., Lecomte, N., Légaré, S., and Bergeron, Y. (2005). Paludification in black spruce (Picea mariana) forests of eastern Canada: potential factors and management implications. Forest Ecol. Manag. 213, 151-159. doi: 10.1016/j.foreco.2005.03.017

Fenton, N. J. (2016). Applied ecology in Canada's boreal: a holistic view of the mitigation hierarchy and resilience theory. Botany 94, 1009-1014. doi: 10.1139/cjb-2016-0123

Foudyl-Bey, S., Brais, S., and Drouin, P. (2016). Litter heterogeneity modulates fungal activity, $\mathrm{C}$ mineralization and $\mathrm{N}$ retention in the boreal forest floor. Soil Biol. Biochem. 100, 264-275. doi: 10.1016/j.soilbio.2016.06.017

Gange, A. C., Allen, L. P., Nussbaumer, A., Gange, E. G., Andrew, C., Egli, S., et al. (2019). Multiscale patterns of rarity in fungi, inferred from fruiting records. Glob. Ecol. Biogeogr. 28, 1106-1117. doi: 10.1111/geb.12918
Glassman, S. I., Levine, C. R., DiRocco, A. M., Battles, J. J., and Bruns, T. D. (2016) Ectomycorrhizal fungal spore bank recovery after a severe forest fire: some like it hot. ISME J. 10, 1228-1239. doi: 10.1038/ismej.2015.182

Greene, D. F., and Johnson, E. A. (1999). Modelling recruitment of Populus tremuloides, Pinus banksiana, and Picea mariana following fire in the mixedwood boreal forest. Can. J. For. Res. 29, 462-473. doi: 10.1139/x98-211

Grogan, P., Barr, J., and Bruns, T. D. (2000). Below-ground ectomycorrhizal community structure in a recently burned bishop pine forest. J. Ecol. 88, 1051-1062. doi: 10.1046/j.1365-2745.2000.00511.x

Hambleton, S., Nickerson, N. L., and Seifert, K. A. (2005). Leohumicola, a new genus of heat-resistant hyphomycetes. Stud. Mycol. 53, 29-52. doi: $10.3114 / \operatorname{sim} .53 .1 .29$

Hart, S. J., Henkelman, J., McLoughlin, P. D., Nielsen, S. E., Truchon-Savard, A., and Johnstone, J. F. (2019). Examining forest resilience to changing fire frequency in a fire-prone region of boreal forest. Glob. Chang. Biol. 25, 869-884. doi: $10.1111 /$ gcb. 14550

Hartig, F. (2019). DHARMa: Residual Diagnostics for Hierarchical (Multi-Level / Mixed) Regression Models. R package v. 0.2.4. Avaliable online at: https://CRAN. R-project.org/package=DHARMa (accessed July 01, 2019)

Hewitt, R. E., Bent, E., Hollingsworth, T. N., Chapin, F. S., and Taylor, D. L. (2013). Resilience of arctic mycorrhizal fungal communities after wildfire facilitated by resprouting shrubs. Ecoscience 20, 296-310. doi: 10.2980/20-3-3620

Hewitt, R. E., Chapin, F. S., Hollingsworth, T. N., and Taylor, D. L. (2017). The potential for mycobiont sharing between shrubs and seedlings to facilitate tree establishment after wildfire at Alaska arctic treeline. Mol. Ecol. 26, 3826-3838. doi: $10.1111 / \mathrm{mec} .14143$

Hewitt, R. E., Hollingsworth, T. N., Stuart Chapin, F., III. and Lee Taylor, D. (2016). Fire-severity effects on plant-fungal interactions after a novel tundra wildfire disturbance: implications for arctic shrub and tree migration. BMC Ecol. 16:25. doi: 10.1186/s12898-016-0075-y

Holden, S. R., Gutierrez, A., and Treseder, K. K. (2013). Changes in soil fungal communities, extracellular enzyme activities, and litter decomposition across a fire chronosequence in Alaskan boreal forests. Ecosystems 16, 34-46. doi: $10.1007 /$ s10021-012-9594-3

Holden, S. R., Rogers, B. M., Treseder, K. K., and Randerson, J. T. (2016). Fire severity influences the response of soil microbes to a boreal forest fire. Environ. Res. Lett. 11:035004. doi: 10.1088/1748-9326/11/3/035004

Houbraken, J., and Samson, R. A. (2011). Phylogeny of Penicillium and the segregation of Trichocomaceae into three families. Stud. Mycol. 70, 1-51. doi: 10.3114/sim.2011.70.01

Izzo, A., Canright, M., and Bruns, T. D. (2006). The effects of heat treatments on ectomycorrhizal resistant propagules and their ability to colonize bioassay seedlings. Mycol. Res. 110, 196-202. doi: 10.1016/j.mycres.2005. 08.010

Jarosz, A. M., and Davelos, A. L. (1995). Effects of disease in wild plant populations and the evolution of pathogen aggressiveness. New Phytol. 129, 371-387. doi: 10.1111/j.1469-8137.1995.tb04308.x

Johnstone, J. F., Allen, C. D., Franklin, J. F., Frelich, L. E., Harvey, B. J., Higuera, P. E., et al. (2016). Changing disturbance regimes, ecological memory, and forest resilience. Front. Ecol. Environ. 14:1311. doi: 10.1002/ fee. 1311

Johnstone, J. F., Chapin, F. S., III, Foote, J., Kemmett, S., Price, K., and Viereck, L. (2004). Decadal observations of tree regeneration following fire in boreal forests. Can. J. For. Res. 34, 267-273. doi: 10.1139/x03-183

Johnstone, J. F., Hollingsworth, T. N., Chapin, F. S., and Mack, M. C. (2010). Changes in fire regime break the legacy lock on successional trajectories in Alaskan boreal forest. Glob. Chang. Biol. 16, 1281-1295. doi: 10.1111/j.1365-2486.2009.02051.x

Kasischke, E. S., and Turetsky, M. R. (2006). Recent changes in the fire regime across the North American boreal region-Spatial and temporal patterns of burning across Canada and Alaska. Geophys. Res. Lett. 33:L09703. doi: 10.1029/2006GL025677

Klironomos, J. N. (2002). Feedback with soil biota contributes to plant rarity and invasiveness in communities. Nature 417, 67-70. doi: 10.1038/417067a

Kohl, L., Philben, M., Edwards, K. A., Podrebarac, F. A., Warren, J., and Ziegler, S. E. (2018). The origin of soil organic matter controls its composition and bioreactivity across a mesic boreal forest latitudinal gradient. Glob. Chang. Biol. 24, e458-e473. doi: 10.1111/gcb.13887 
Kõljalg, U., Nilsson, R. H., Abarenkov, K., Tedersoo, L., Taylor, A. F. S., Bahram, M., et al. (2013). Towards a unified paradigm for sequence-based identification of fungi. Mol. Ecol. 22, 5271-5277. doi: 10.1111/mec.12481

Kuo, H.-C., Hui, S., Choi, J., Asiegbu, F. O., Valkonen, J. P. T., and Lee, Y.-H. (2015). Secret lifestyles of Neurospora Crassa. Sci. Rep. 4:5135. doi: $10.1038 /$ srep05135

Kyaschenko, J., Clemmensen, K. E., Karltun, E., and Lindahl, B. D. (2017). Below-ground organic matter accumulation along a boreal forest fertility gradient relates to guild interaction within fungal communities. Ecol. Lett. 20, 1546-1555. doi: 10.1111/ele.12862

Laganière, J., Paré, D., and Bradley, R. L. (2010). How does a tree species influence litter decomposition? Separating the relative contribution of litter quality, litter mixing, and forest floor conditions. Can. J. For. Res. 40, 465-475. doi: 10.1139/X09-208

Larsson, C. (2006). CooRecorder and Cdendro programs of the CooRecorder/Cdendro package. version 7.8. Avaliable online at: http:// www.cybis.se/forfun/dendro/ (accessed May 27, 2020).

Lenth, R. V. (2016). Least-squares means: the R package lsmeans. J. Stat. Softw. 69, 1-33. doi: 10.18637/jss.v069.i01

Lüdecke, D. (2018). ggeffects: Tidy data frames of marginal effects from regression models. JOSS 3:772. doi: 10.21105/joss.00772

Nguyen, H. D. T., and Seifert, K. A. (2008). Description and DNA barcoding of three new species of Leohumicola from South Africa and the United States. Persoonia 21, 57-69. doi: 10.3767/003158508X361334

Nguyen, N. H., Song, Z., Bates, S. T., Branco, S., Tedersoo, L., Menke, J., et al. (2016). FUNGuild: an open annotation tool for parsing fungal community datasets by ecological guild. Fungal Ecol. 20, 241-248. doi: 10.1016/j.funeco.2015.06.006

Pan, Y., Birdsey, R. A., Fang, J., Houghton, R., Kauppi, P. E., Kurz, W. A., et al. (2011). A large and persistent carbon sink in the world's forests. Science 333, 988-993. doi: 10.1126/science.1201609

Peay, K. G., Garbelotto, M., and Bruns, T. D. (2009). Spore heat resistance plays an important role in disturbance-mediated assemblage shift of ectomycorrhizal fungi colonizing Pinus muricata seedlings. J. Ecol. 97, 537-547. doi: 10.1111/j.1365-2745.2009.01489.x

Peterson, S. W., Jurjevic, Z., Bills, G. F., Stchigel, A. M., Guarro, J., and Vega, F. E. (2010). Genus Hamigera, six new species and multilocus DNA sequence based phylogeny. Mycologia 102, 847-864. doi: 10.3852/09-268

Pinheiro, J., Bates, D., DebRoy, S., Sarkar, D., and R. Core Team (2019). nlme: Linear and Nonlinear Mixed Effects Models. R package version 3.1-139. Available online at: http://CRAN.R-project.org/package=nlme (accessed May 27, 2017)

Porras-Alfaro, A., and Bayman, P. (2011). Hidden fungi, emergent properties: endophytes and microbiomes. Annu. Rev. Phytopathol. 49, 291-315. doi: 10.1146/annurev-phyto-080508-081831

Prescott, C. E. (2010). Litter decomposition: what controls it and how can we alter it to sequester more carbon in forest soils? Biogeochemistry 101, 133-149. doi: 10.1007/s10533-010-9439-0

Prescott, C. E., Maynard, D. G., and Laiho, R. (2000). Humus in northern forests: friend or foe? Forest Ecol. Manag. 133, 23-36. doi: 10.1016/S0378-1127(99)00295-9

Preston, C. M., Bhatti, J. S., and Norris, C. E. (2014). Chemical quality of aboveground litter inputs for jack pine and black spruce stands along the Canadian boreal forest transect case study. Écoscience 21, 202-216. doi: $10.2980 / 21-(3-4)-3690$

R Core Development Team (2019). R: A Language and Environment for Statistical Computing v. 3.6.0. Vienna: R Foundation for Statistical Computing. Available online at: http://www.R-project.org/ (accessed July 02, 2019)

Reid, K. (2017). Effects of wildfires on tree establishment in conifer-dominated boreal forests in southern Northwest Territories. (Ph.D. thesis). Department of Biology, Faculty of Science in partial fulfilment of the requirement for the Master of Science in Integrative Biology Wilfrid Laurier University.

Rogers, B. M., Veraverbeke, S., Azzari, G., Czimczik, C. I., Holden, S. R., Mouteva, G. O., et al. (2014). Quantifying fire-wide carbon emissions in interior Alaska using field measurements and Landsat imagery: modeling fire emissions with dNBR. J. Geophys. Res.-Biogeo. 119, 1608-1629. doi: 10.1002/2014JG 002657

Romero-Olivares, A. L., Meléndrez-Carballo, G., Lago-Lestón, A., and Treseder, K. K. (2019). Soil metatranscriptomes under long-term experimental warming and drying: Fungi allocate resources to cell metabolic maintenance rather than decay. Front. Microbiol. 10:1914. doi: 10.3389/fmicb.2019. 01914

Samson, R. A., Houbraken, J., Thrane, U., Frisvad, J. C., and Andersen, B. (2010). Food and Indoor Fungi. Utrecht: CBS-KNAW Fungal Biodiversity Centre.

Schäfer, W., Straney, D., Ciuffetti, L., Van Etten, H. D., and Yoder, O. C. (1989). One enzyme makes a fungal pathogen, but not a saprophyte, virulent on a new host plant. Science 246, 247-249. doi: 10.1126/science.246. 4927.247

Shah, F., Nicolás, C., Bentzer, J., Ellström, M., Smits, M., Rineau, F., et al. (2016). Ectomycorrhizal fungi decompose soil organic matter using oxidative mechanisms adapted from saprotrophic ancestors. New Phytol. 209, 1705-1719. doi: 10.1111/nph.13722

Shenoy, A., Johnstone, J. F., Kasischke, E. S., and Kielland, K. (2011). Persistent effects of fire severity on early successional forests in interior Alaska. For. Ecol.Manag. 261, 381-390. doi: 10.1016/j.foreco.2010.10.021

Smith, G. R., Finlay, R. D., Stenlid, J., Vasaitis, R., and Menkis, A. (2017). Growing evidence for facultative biotrophy in saprotrophic fungi: data from microcosm tests with 201 species of wood-decay basidiomycetes. New Phytol. 215, 747-755. doi: $10.1111 /$ nph.14551

Smith, S. E., and Read, D. (2008). Mycorrhizal Symbiosis, 3th Edn. New York, NY: Elsevier Ltd.

Sterkenburg, E., Bahr, A., Brandström Durling, M., Clemmensen, K. E., and Lindahl, B. D. (2015). Changes in fungal communities along a boreal forest soil fertility gradient. New Phytol. 207, 1145-1158. doi: 10.1111/nph. 13426

Summerbell, R. C. (2005). Root endophyte and mycorrhizosphere fungi of black spruce, Picea mariana, in a boreal forest habitat: influence of site factors on fungal distributions. Stud. Mycol. 53, 121-145. doi: 10.3114/sim. 53.1 .121

Sun, H., Santalahti, M., Pumpanen, J., Köster, K., Berninger, F., Raffaello, T., et al. (2015). Fungal community shifts in structure and function across a boreal forest fire chronosequence. Appl. Environ. Microbiol. 81, 7869-7880. doi: 10.1128/AEM.02063-15

Suryanarayanan, T. S., Govindarajulu, M. B., Thirumalai, E., Reddy, M. S., and Money, N. P. (2011). Agni's fungi: heat-resistant spores from the Western Ghats, southern India. Fungal Biol. 115, 833-838. doi: 10.1016/j.funbio.2011.06.011

Thormann, M. N., and Rice, A. V. (2007). Fungi from peatlands. Fungal Divers. 24, 241-299.

Thorn, R. G., Reddy, C. A., Harris, D., and Paul, E. A. (1996). Isolation of saprophytic basidiomycetes from soil. Appl. Environ. Microbiol. 62, 4288-4292. doi: 10.1128/AEM.62.11.4288-4292.1996

Treseder, K. K., Bent, E., Borneman, J., and McGuire, K. L. (2014). Shifts in fungal communities during decomposition of boreal forest litter. Fungal Ecol. 10, 58-69. doi: 10.1016/j.funeco.2013.02.002

Treseder, K. K., Mack, M. C., and Cross, A. (2004). Relationships among fires, fungi, and soil dynamics in Alaskan boreal forests. Ecol. Appl. 14, 1826-1838. doi: 10.1890/03-5133

Visagie, C. M., Houbraken, J., Frisvad, J. C., Hong, S. B., Klaassen, C. H. W., Perrone, G., et al. (2014). Identification and nomenclature of the genus Penicillium. Stud. Mycol. 78, 343-371. doi: 10.1016/j.simyco.2014.09.001

Walker, X. J., Baltzer, J. L., Cumming, S. G., Day, N. J., Ebert, C., Goetz, S., et al. (2019). Increasing wildfires threaten historic carbon sink of boreal forest soils. Nature 572, 520-523. doi: 10.1038/s41586-019-1474-y

Walker, X. J., Baltzer, J. L., Cumming, S. G., Day, N. J., Johnstone, J. F., Rogers, B. M., et al. (2018b). Soil organic layer combustion in boreal black spruce and jack pine stands of the Northwest Territories, Canada. Int. J. Wildland Fire 27, 125-134. doi: 10.1071/WF17095

Walker, X. J., Rogers, B. M., Baltzer, J. L., Cumming, S. G., Day, N. J., Goetz, S. J., et al. (2018a). Cross-scale controls on carbon emissions from boreal forest megafires. Glob. Chang. Biol. 24, 4251-4265. doi: 10.1111/gcb. 14287

Walker, X. J., Rogers, B. M., Baltzer, J. L., Cumming, S. G., Day, N. J., Goetz, S. J., et al. (2018c). ABoVE: Wildfire carbon emissions at 30-m resolution, Northwest Territories, CA, 2014. Oak Ridge, Tennessee: ORNL DAAC. Available online at: https://doi.org/10.3334/ORNLDAAC/1561 (accessed September 28, 2018). 
Wang, T., Hamann, A., Spittlehouse, D. L., and Murdock, T. Q. (2012). ClimateWNA-High-resolution spatial climate data for western North America. J. Appl. Meteor. Climatol. 51, 16-29. doi: 10.1175/JAMC-D11-043.1

White, A. L. (2018). Drivers of post-fire vascular plant regeneration in the conifer-dominated boreal forest of southern Northwest Territories (Ph.D. thesis). Department of Biology Faculty of Science in partial fulfilment of the requirements for the Master of Science in Integrative Biology Wilfrid Laurier University, Waterloo, ON, Canada.

Whitman, E., Parisien, M.-A., Thompson, D., and Flannigan, M. (2018). Topoedaphic and forest controls on post-fire vegetation assemblies are modified by fire history and burn severity in the northwestern Canadian boreal forest. Forests 9:151. doi: 10.3390/f9030151

Wickham, H. (2017). tidyverse: Easily Install and Load the "Tidyverse." Avaliable online at: https://CRAN.R-project.org/package=tidyverse (accessed April 17, 2018)

Wotton, B. M., Flannigan, M. D., and Marshall, G. A. (2017). Potential climate change impacts on fire intensity and key wildfire suppression thresholds in Canada. Environ. Res. Lett. 12:095003. doi: 10.1088/1748-9326/aa7e6e
Zhang, D., Hui, D., Luo, Y., and Zhou, G. (2008). Rates of litter decomposition in terrestrial ecosystems: global patterns and controlling factors. J. Plant Ecol. 1, 85-93. doi: 10.1093/jpe/rtn002

Zhang, T., Barry, R. G., Knowles, K., Heginbottom, J. A., and Brown, J. (1999). Statistics and characteristics of permafrost and ground-ice distribution in the Northern Hemisphere. Polar Geogr. 23, 132-154. doi: $10.1080 / 10889379909377670$

Conflict of Interest: The authors declare that the research was conducted in the absence of any commercial or financial relationships that could be construed as a potential conflict of interest.

Copyright (C) 2020 Day, Cumming, Dunfield, Johnstone, Mack, Reid, Turetsky, Walker and Baltzer. This is an open-access article distributed under the terms of the Creative Commons Attribution License (CC BY). The use, distribution or reproduction in other forums is permitted, provided the original author $(s)$ and the copyright owner(s) are credited and that the original publication in this journal is cited, in accordance with accepted academic practice. No use, distribution or reproduction is permitted which does not comply with these terms. 